$\begin{array}{lll}\text { Journal of } & \text { Vol 2 (1): Pages 17-37 (2021) } \\ \text { ECOSCIENCE } & \text { DOI 10.37357/1068/iepr.2.1.03 } \\ \text { AND PLANT } & \text { ISS 2435-7294 Check for updates } \\ \text { REVOLUTION } & \text { A) Coscience }\end{array}$

\title{
Afghanistan aquaculture and fishery sectors - A foresight outlooks
}

Mir Sayed Shah Danish ${ }^{1}$, Abdul Matin Ibrahimi ${ }^{1}$, Mohammad Aman Yaqobi ${ }^{1}$, Shingo Udagawa ${ }^{1}$, Alexey Mikhaylov ${ }^{2}$, Nadeem Faisal ${ }^{3}$ and Tomonobu Senjyu ${ }^{4}$

1Strategic Research Project Center, University of the Ryukyus, 1 Senbaru, Nishihara, Okinawa 9030213, Japan

2Financial University under the Government of the Russian Federation, Leningradsky Ave, 49, Moscow 125167, Russia

${ }^{3}$ Central Institute of Petrochemicals Engineering and Technology, Centre for Skilling and Technical Support, Balasore, Odisha, India

${ }^{4}$ Department of Electrical and Electronics Engineering, Faculty of Engineering, University of the Ryukyus, 1 Senbaru, Nishihara, Okinawa 903-0213, Japan

\section{Article}

Open Access

Published

Keywords

- Afghanistan aquaculture

- Afghanistan fishery

- Afghanistan fish market

- Aquaculture indicators

- Aquaculture economic indicators

- Aquaculture production indicators

- Food security

- Aquaculture sustainability

- Sustainable development goals (SDGs)

\section{ABSTRACT}

Aquaculture systems and technologies are growing industries in many countries with high environmental and socio-economic advantages. Afghanistan, a landlocked country in South Asia with diverse geographic and ecological features, reported the lowest fish consumption rate (just above $2 \mathrm{~kg}$ per capita). After conflicts and instability in Afghanistan, aquaculture and fisheries sectors revived slowly, followed by a rapid production and demand increase in the last four years. However, Afghanistan can demonstrate with a long history of fishery and agriculture productions in the past, but the post-conflict and stability efforts are minimal. Therefore, Afghanistan's aquaculture and fisheries sectors are conventional and require more effort to study and propose viable solutions aligned with today's technological and sustainability requirements. Adequate and historically documented information about Afghanistan's aquaculture and fisheries activities are pretty limited. This study covers previous aquaculture initiatives, establishes a thematic review of the current situation based on little available information, and follows by a foresight outlook of the future trends. Besides, it presents the essential factors associated with production-efficient aquaculture and fishery systems in light of economic and production performance indicators. These indicators are briefly discussed that contribute to system planners and practitioners in decision-making and optimizing economic and operational efficiencies. Besides of studying Afghanistan aquaculture and fishery sectors, the basic criteria for successful small scale aquaculture are also presented that can be counted as one of the recent compositions of the subject in terms of scholarly managed information within an exhaustive insight.

Received: July 20, 2021; Revised: August 10, 2021; Accepted: August 11, 2021; Published: August, 20, 2021 (c)2021 REPA. All rights reserved.

\section{Introduction}

After suffering two world wars, food security and hunger were counted as the main challenges of the nations. Overcoming this challenge, the Food and Agriculture Organization (FAO) was founds in 1945 as a specialized agency of the United Nations that leads international efforts to defeat hunger [1]. The FAO declares that "We believe that everyone can play a part in ending hunger." Simultaneously, irradicating hunger shall comply with sustainability five pillars' requirements [2] without compromising biodiversity and ecosystem. Not only enough food, but the variety of mix of food with balanced nutrients, preventing grow sickness or death. The world population is growing fast, doubled in the last few decades, whereas almost all resources remain the same.

Aquaculture and fishery sectors can be the main contributors, mitigating hanger, food insecurity, and malnutrition in developing nations; combating greenhouse gas emissions and biodiversity distress in developed nations to retain the second Sustainable Development Goal (SDGs) goal. Many explanations refer to sustainability [3-5] that the concept of sustainability in aquaculture can be defined use for sufficiently supplying systems, for now, and does not compromise the ability of future generations to meet their needs [6] without environmental impacts on air, water, and soil quality [7]. The concept of sustainable energy deployment falls under main five categories to be observed as follows [8]:

1- Technical sustainability

2- Economic sustainability

3- Institutional sustainability

4- Environmental sustainability

5- Social sustainability

So far, studies on aquaculture and fishery sectors of Afghanistan are limited due to scarcity of information and available data because of past conflict and insecurity incidents in the country. Available information of the recent years is available in the form of scattered information accumulated in reports and government documents in local languages. However, before the conflict incidents in Afghanistan, valuable studies explored the fish species of the Middle East, including Afghanistan from since the 1950s [9]. Also, recently conducted studies on the South Asia region (Afghanistan, Bangladesh, Bhutan, India, Maldives, Nepal, Pakistan, and Sri Lanka) agriculture and fisheries sectors, excluding Afghanistan from the study due to 
inaccessibility to the information $[10,11]$. Therefore, this study can be counted as a scholarly effort towards recent trends and future outlook regarding aquaculture and fisheries sectors in Afghanistan.

This study conducts a review based on available information about Afghanistan fishery and aquaculture. Since there is limited available information about aquaculture, therefore this topic is briefly reported.

\section{Brief update on aquaculture}

Aquaculture embodies understanding, growing, consuming, and managing aquatic organisms, including fish, molluscs, crustaceans and aquatic plants. Modern aquaculture (1750-1880) refers to China in the middle of the second millennium that slowly was taken up by the Japanese people [12]. In the past five decades, with increasing population and growing food demand, aquaponics systems utilization, including hydroponics and aquaculture productions, has doubled [13]. This rapid development follows contemporary technical and technological improvement while exploiting natural resources, and environmental impact remains a risk to mitigate optimally.

World aquatic industry productions have a rapid growth of more than $527 \%$ in aquaculture and $14 \%$ in fisheries productions from 1990 to 2018 [14]. These figures optimistically encourage development trends of aquaponics and aquaculture systems aligned with today's cutting-edge technologies. Meanwhile, aquatic farms' ecological and environmental distresses are the turning point requiring exhaustive measures and even replicating or readapt of successful policies within the recent constrained environmental disaster. Aquaponics environmental impact comprises factors that complicate qualitatively constrain airborne and waterborne emissions [15] within the acceptable permitted range for maintaining environmental sustainability in the long run.

Aquaculture supports goal 14 of the sustainable development goals (SDGs) that recommend the "conserve and sustainably use the oceans, seas and marine resources for sustainable development." Whereas, supplementarily fisheries and aquaculture industries' production and operation contribute SDGs goals 2, 7, 8, 12, and 14 directly and indirectly, i.e. [16].

- SDGs 2: Zero hunger - maintaining food security by producing aquatic animal species, and aquatic plants products (Figure 1 [17]).

- SDG7: Sustainable and modern energy production and supply-feeding aquaponics system by renewable energy technologies with minimum environmental pollution impact with high affordability, accessibility, controllability, manageability, and automation, deployment of cutting-edge technologies, i.e., internet of things (IoT), artificial intelligence (AI), etc.

- SDG8: Economic growth - empowering local residents by providing food, nutrition, employment, and sustaining local markets. Aquaponics enables a new measure to grow sustainable fish and veggies cost-effectively, which can help in improving accessibility to affordable food with local economic benefits.

- SDG12: Balance consumption and production - balancing local demands and consumption that reduce the tendency to import and export, enhance socioeconomic and environmental distress impacts due to supply chain i.e., transportation, conservation, distribution, and retailing of the products. This supply chain incorporated investing money, wasting power energy and products, with the final stale product to the consumer.

- SDG14: Marine resources conservation - enlivening the marine ecosystem, which discontented with human being treatment over the past decades.

- World most accepted ASFIS (Aquatic Sciences and Fisheries Information System) species by value in 2017 are reported: White leg shrimp, Atlantic salmon, Grass carp, Silver carp, Red swamp crawfish, Chinese mitten crab, Common carp, Nile tilapia, Bighead carp, Japanese carpet shell, etc. [18]. 


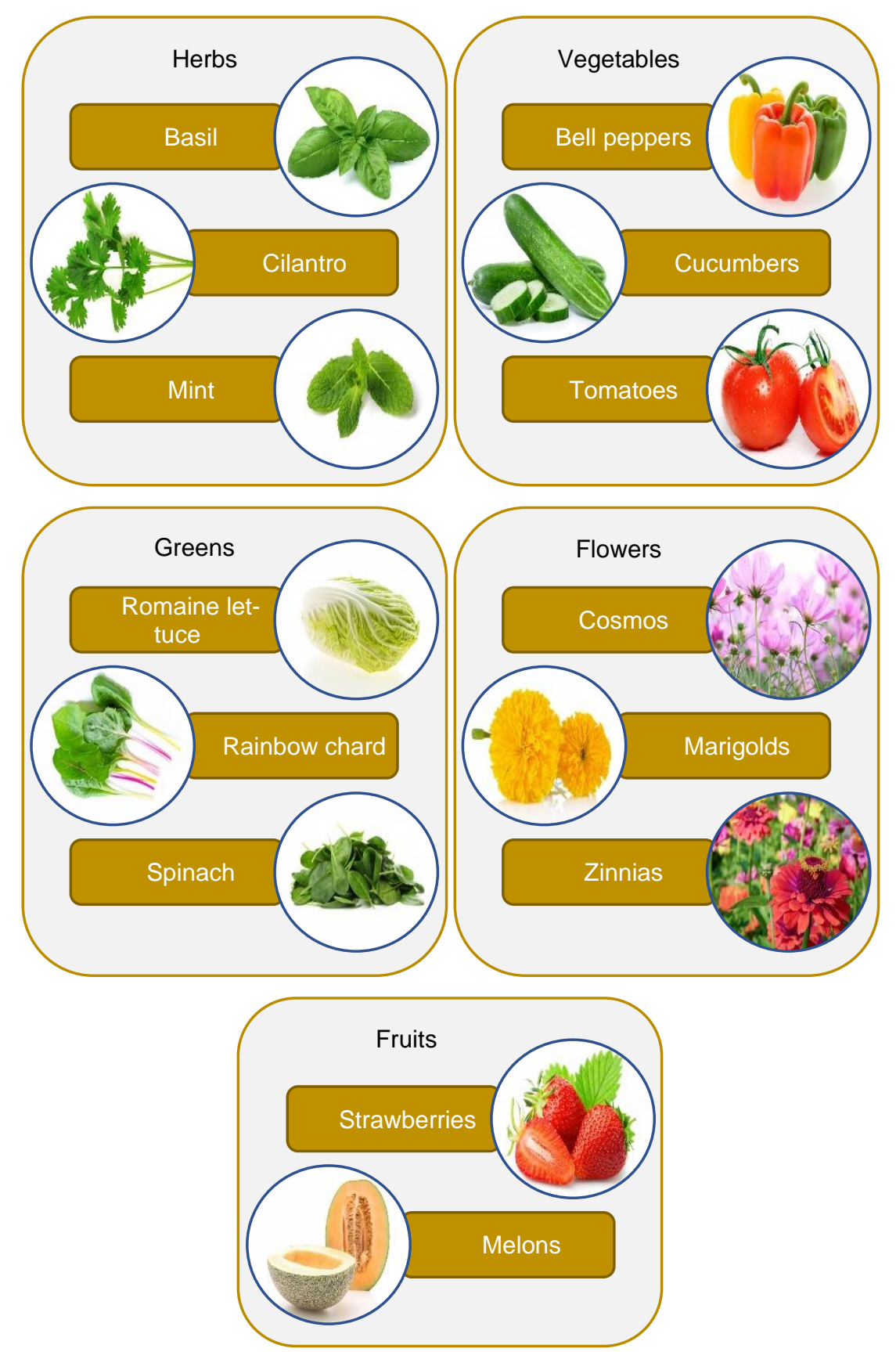

Figure 1. The most aquatic-friendly farms' products with multiple cropping potential compared to soil-based traditional farms 


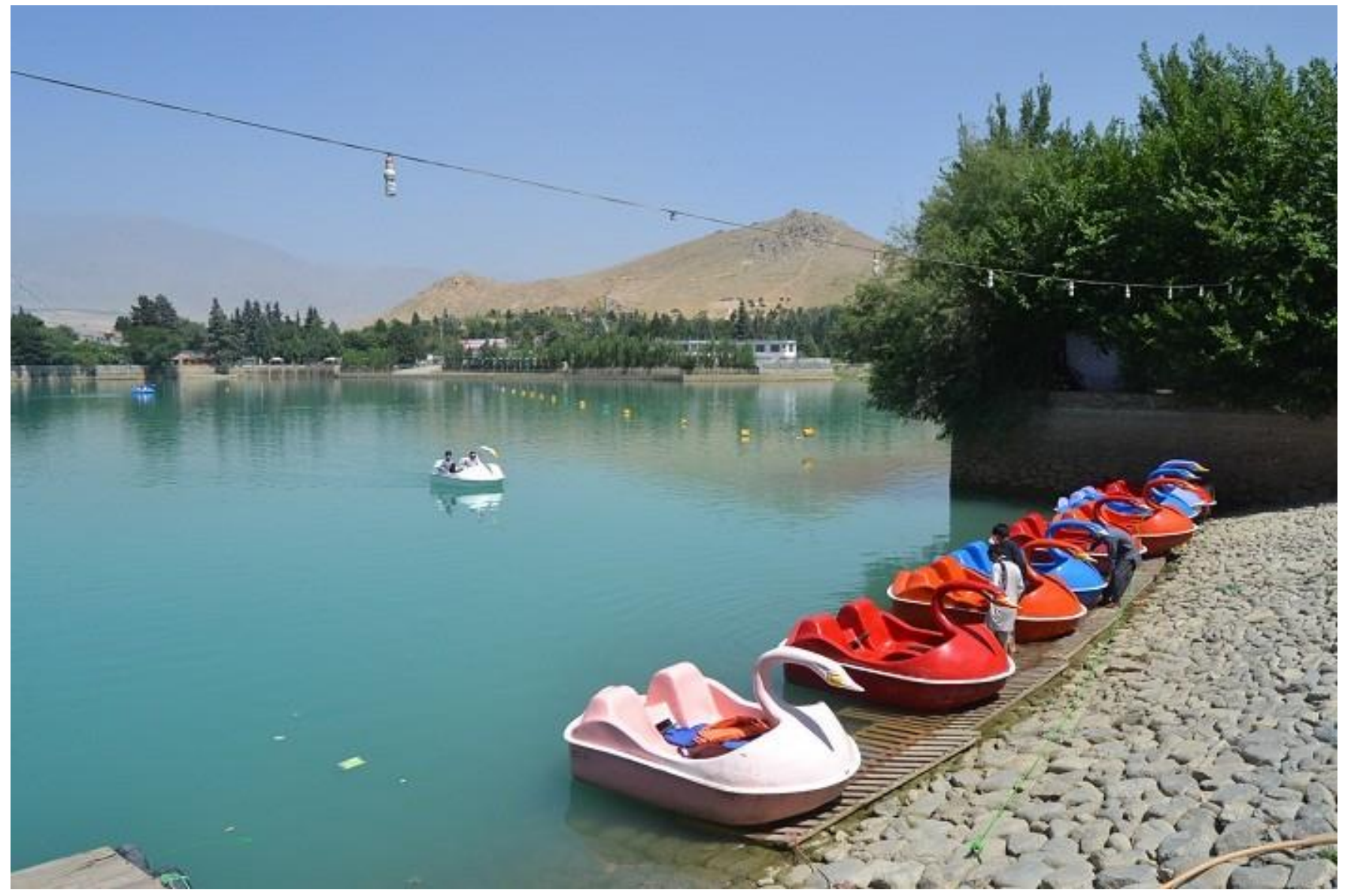

Figure 2. Qargha lake view in Kabul, Afghanistan [19].

After decades of conflict and instability in Afghanistan, livelihoods and food security programs under the agriculture and fisheries has major progress. Aquaculture and fisheries forms in Afghanistan are getting growing attention and transforming into the modern system with the help of international cooperation. Since the end of the conflict and instability incident in Afghanistan (2001), FAO, the government of Japan, the World Bank, and many donors empowered over 400,000 farm households, covering over 2 million people with the rehabilitation of aquaculture facilities, including agriculture and fisheries [20]. Still, aquaculture production is a diverse activity in Afghanistan in the context of forming, utilization, and types; rural types of aquacultures are mostly welcomed in terms of basic production systems. Warm and cold water aquatics species are usual in Afghanistan, such as Rainbow trout, Tor, Schizothorax, Channidae, Siluridae/Clariidae, Salmo trutta, Carp, Barbel, etc. [21]. And the most famous species are salmon and halibut raising in natural water [22]. 


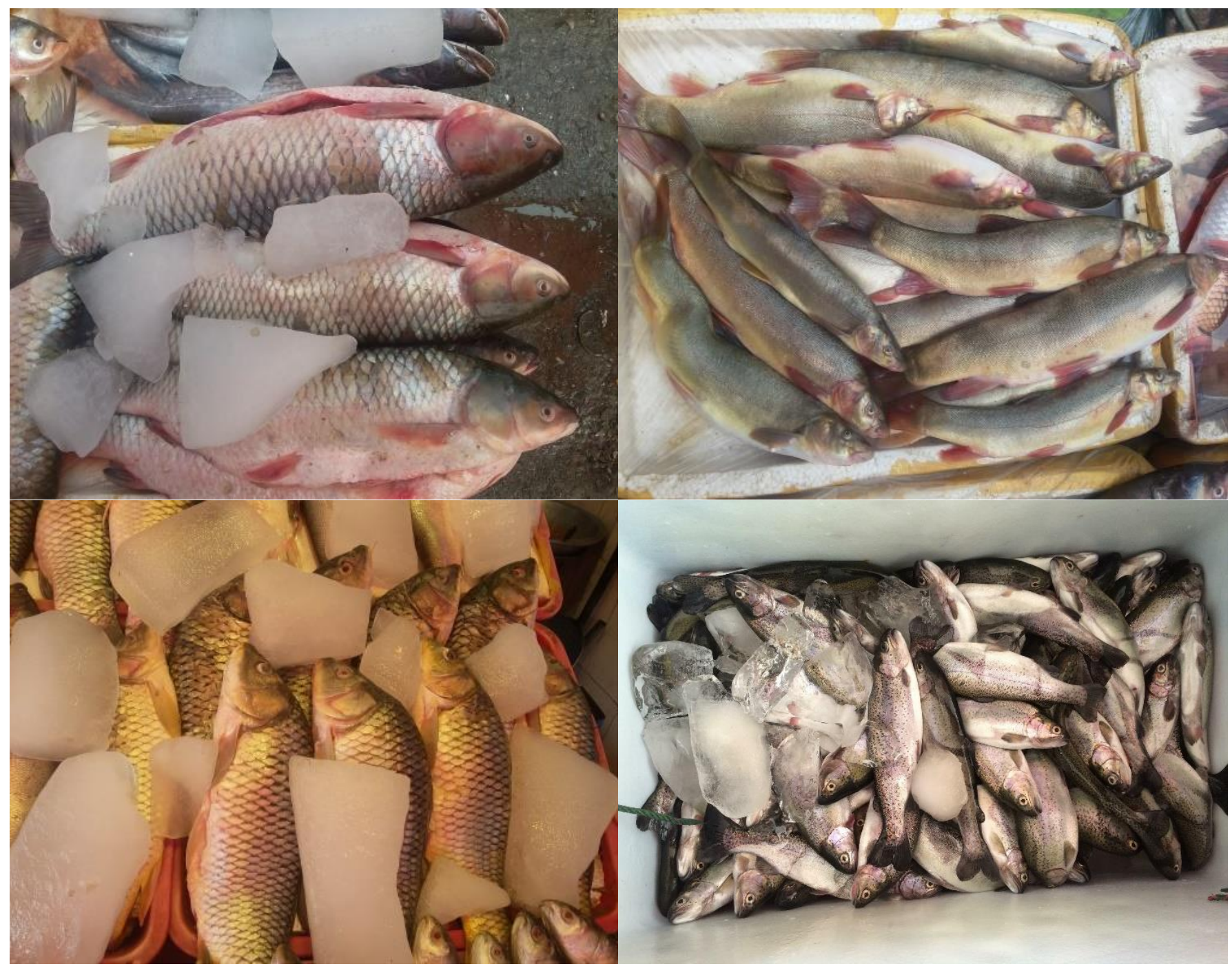

Figure 3. Some species of fish in Afghanistan [23,24].

Maintaining risk-free biodiversity and the ecosystem for fish is essential. In [25], 129 species of freshwater fishes are introduced to Afghanistan. According to the World Atlas, various species of fish are listed under the native fish of Afghanistan in Table 1. Historically, in the past, different species of freshwater fishes are reported from Afghanistan [26].

Table 1: Native fish of Afghanistan [27].

\begin{tabular}{llll}
\hline $\begin{array}{l}\text { Native Fish of Scientific } \\
\text { Afghanistan }\end{array}$ & $\begin{array}{l}\text { Game } \\
\text { Length }\end{array}$ & $\begin{array}{l}\text { Growth Environment } \\
\text { and Breeding Season }\end{array}$ \\
\hline $\begin{array}{l}\text { Schneider Rif- } \\
\text { Al- } \\
\text { fle Minnow }\end{array}$ & $\begin{array}{l}\text { burnoides } \\
\text { bipunctatus }\end{array}$ & 3.5 inches & $\begin{array}{l}\text { Slow moving rivers; } \\
\text { Breeding season is be- } \\
\text { tween April and June } \\
\text { Lakes and deep, slow } \\
\text { moving rivers; }\end{array}$ \\
$\begin{array}{llll}\text { Helicopter } \\
\text { Catfish }\end{array}$ & $\begin{array}{l}\text { Wallago } \\
\text { attu }\end{array}$ & $\begin{array}{l}\text { Up to } 96 \\
\text { inches }\end{array}$ & $\begin{array}{l}\text { Due to overfishing, its } \\
\text { population has drasti- } \\
\text { cally declined }\end{array}$
\end{tabular}

Schizopy- up to $13 \quad$ Mountain rivers and

False Osman gopsis stol- up to 13 iczkai

\begin{tabular}{|c|c|c|}
\hline Tibetan Stone & TriplophysaUp to 6.4 & Higher altitudes: riv- \\
\hline $\begin{array}{l}\text { Turkestan } \\
\text { Sisorid Catfis }\end{array}$ & $\begin{array}{l}\text { Glyptoster- } \\
\text { non reticu- Up to } 9 \\
\text { latum }\end{array}$ & $\begin{array}{l}\text { Fast-moving water: } \\
\text { Prefers to stay under } \\
\text { rocks at the bottom of } \\
\text { the riverbed }\end{array}$ \\
\hline
\end{tabular}

Indus River Rita

Bagrid Catfish macracan- 10 inches

Giant River Sperata Around 15

Catfish $\quad$ seenghala inches

Griffith's Triplophysa 8.3 inches

$\begin{array}{lll}\text { Griffith's } & \text { Triplophysa } \\ \text { Stone Loach } & \text { griffithii } & \text { Fresh water }\end{array}$

Helmand

River Stone $\quad$ Triplophysa $_{\mathrm{N}}$ /A

Loach

Breeding season is between June and July

Popular for human consumption and for sports fishing

Afghanistan is one of the lowest fish consumption rate countries in the world. The highest fish consumption (per capita) is reported over $50 \mathrm{~kg}$ in Oceania, and lower consumption per capita in some landlocked countries such as Afghanistan, Ethiopia, and Lesotho just above $2 \mathrm{~kg}$ [28]. 
However, fish is one of the most popular foods in Afghanistan's second half of the year [29]. On average, $1 \mathrm{~kg}$

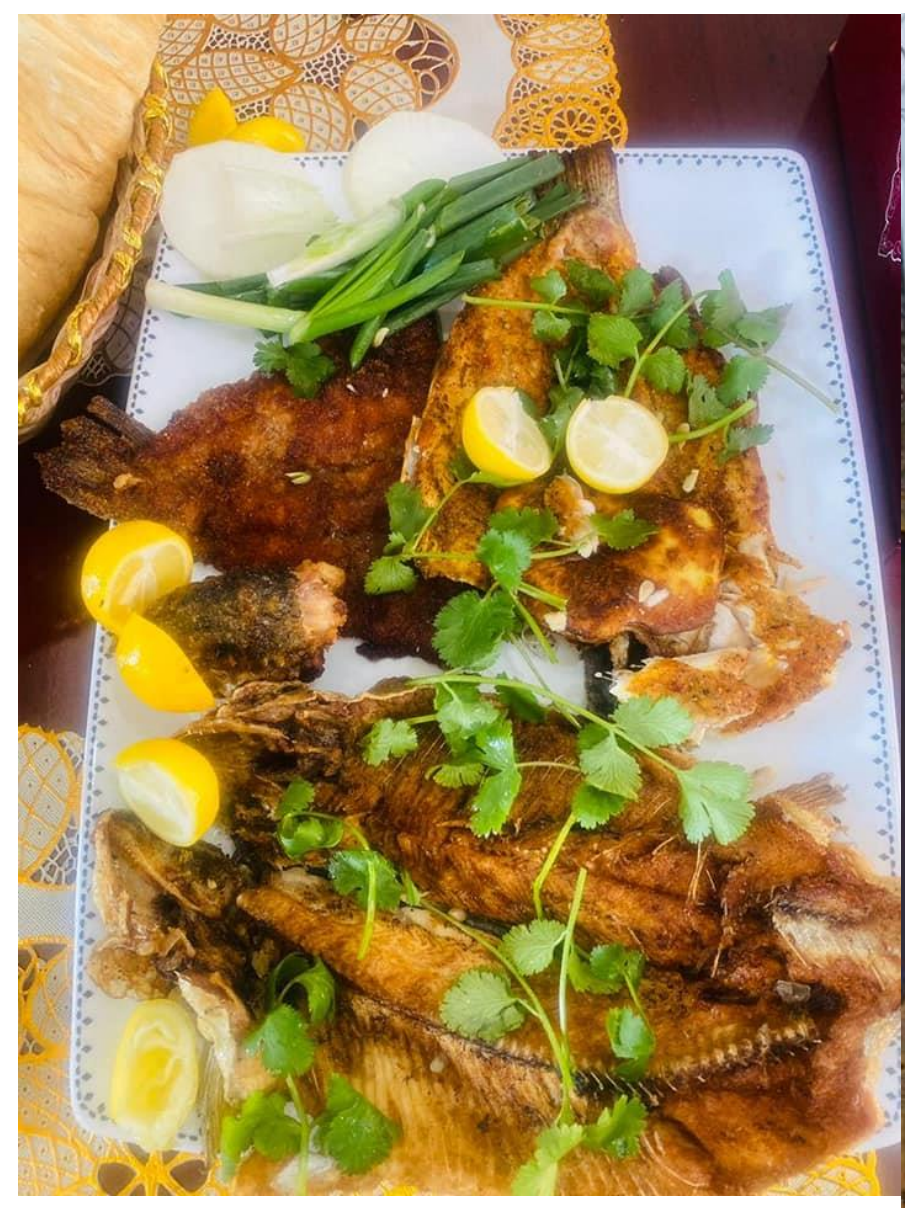

Figure 4. Afghanistan fish kabab [30,31]. (cooked or fresh) fish in Afghanistan costs 220 AFG (2.85 USD) that is often cooking as kabab (Figures 4-5).

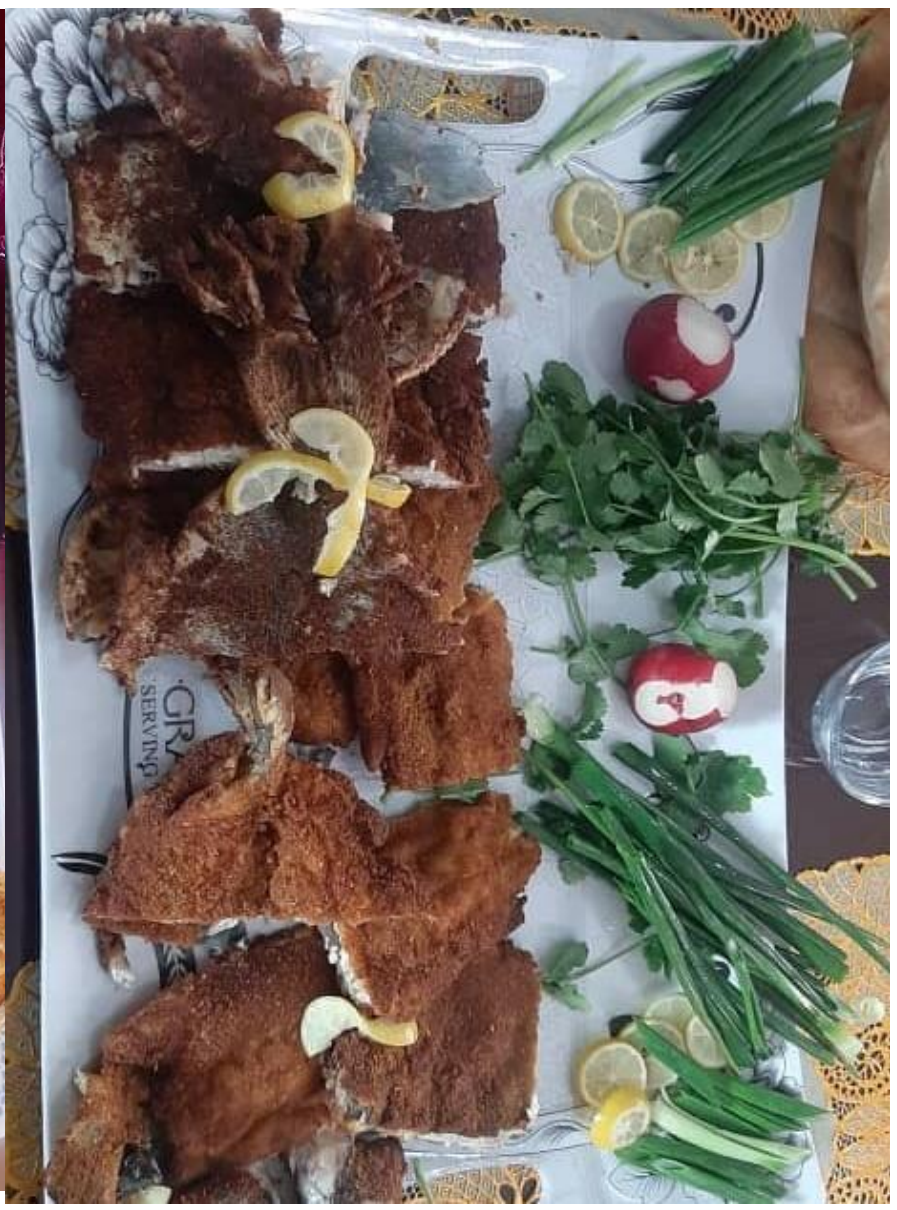




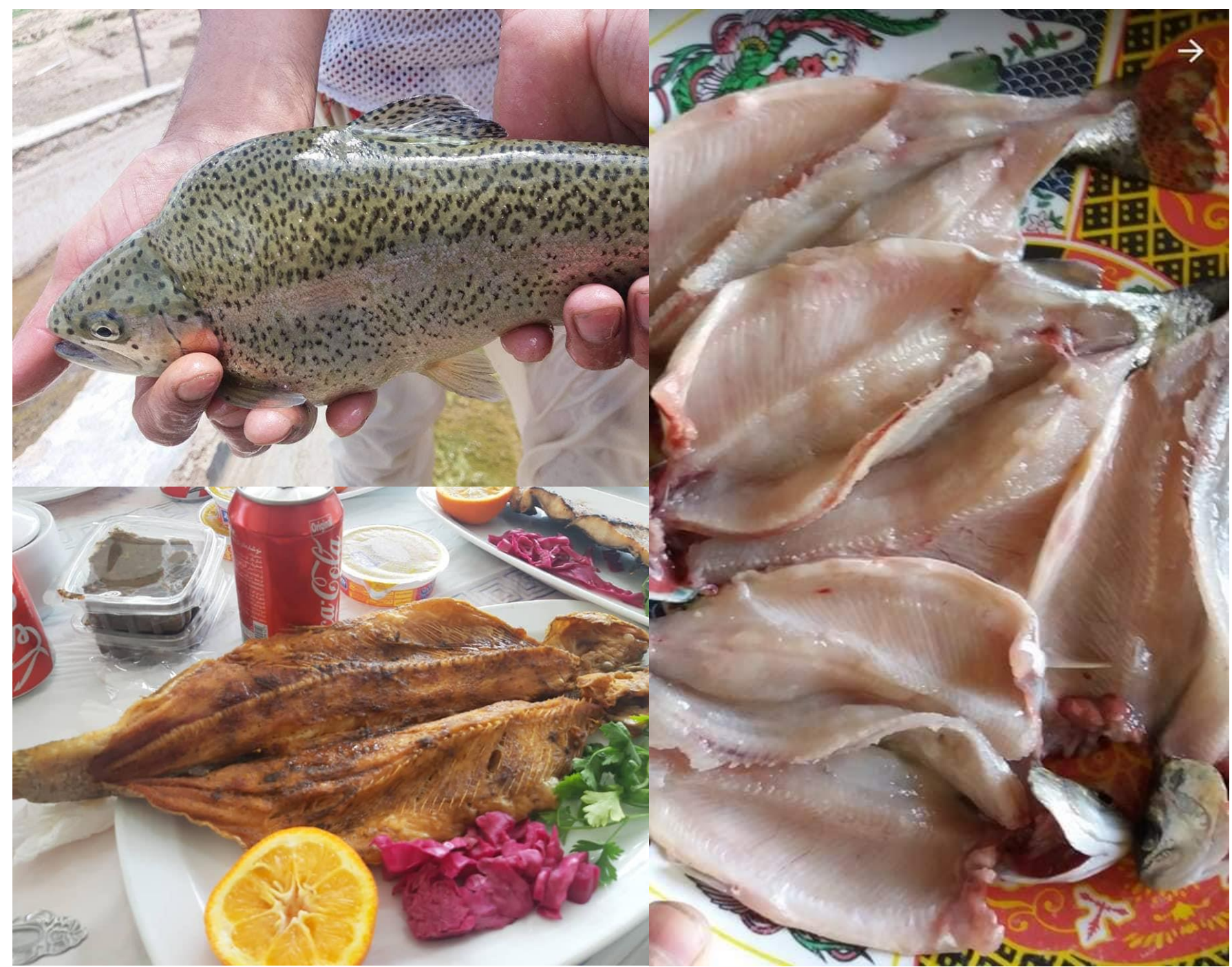

Figure 5. Afghanistan Salmon fish kabab [32-34].

Various ingredients vary depending on feeding strategies, species, environmental, the intensity of production factors, etc. The common feeding ingredients for fish feeding in Afghanistan containing wheat, blood, animal offal/intestines, cotton seed, vegetable trimmings, spoiled fruits and vegetables, pulses/legumes, alfalfa, and so on [21].

\section{Current situation}

However, there is no adequate information about Afghanistan aquaculture. Based on statistics and reports, aquaculture production grew from 870 tonnes in 1980 to around 1250 - 1600 tonnes in 1990-2006 that followed with demanding increase [35]. It is preferred to focus on development and annual growth trends rather than figures of production values to figure out the prospect.

Aquaculture and fisheries production in Afghanistan is associated with some opportunities (low cost of labor and land availability) and bottlenecks (lack of skilled workers, unavailability of the government subsidies and support until production). Investment in aquaculture and fish farms is competitive that construction of six fish ponds with the size of $20 \mathrm{~m} \times 25 \mathrm{~m} \times 1.5 \mathrm{~m}$ with necessary equipment has cost around 31 million AFN (40,000 USD) with a monthly average return on investment (ROI) of 174,487 AFN (2,250 USD) [36]. According to the recent reports [35], Afghanistan aquaculture statistics are mapped in Figures 6-8. 


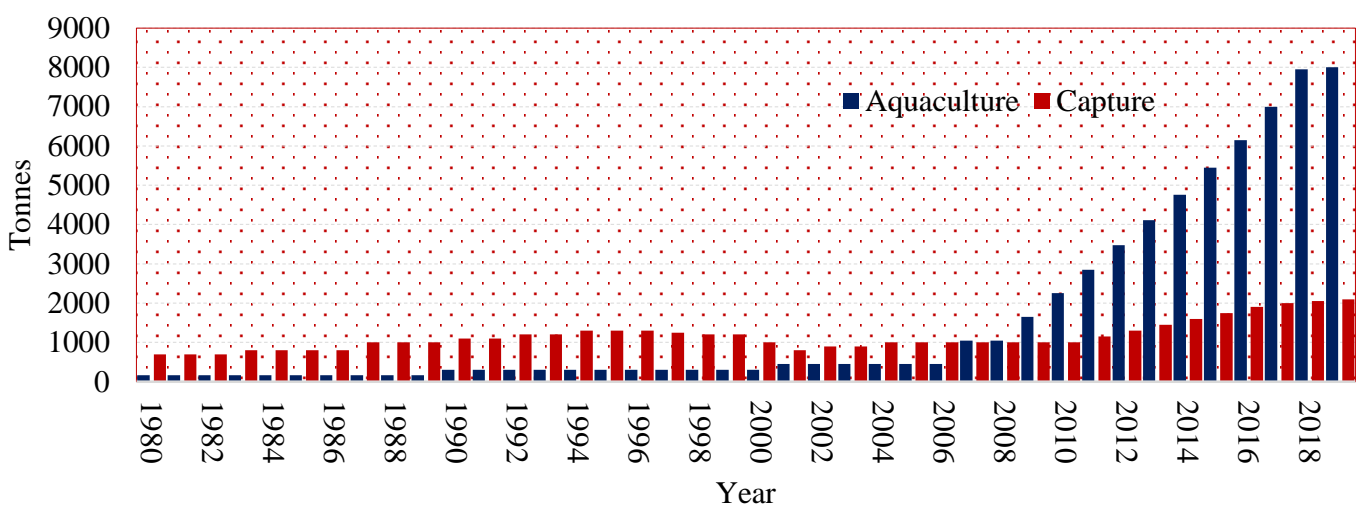

Figure 6. Annual total aquaculture production and capture between 1980-2019.

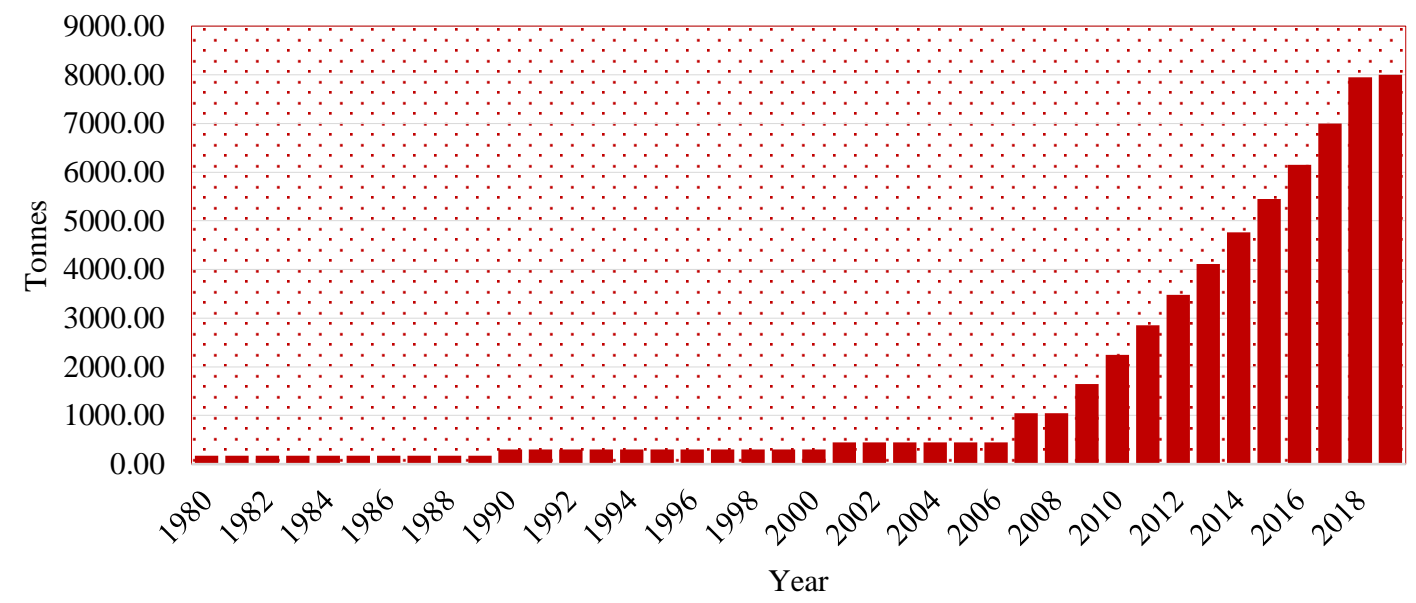

Figure 7. Afghanistan annual aquaculture production between 1980-2019 (freshwater).

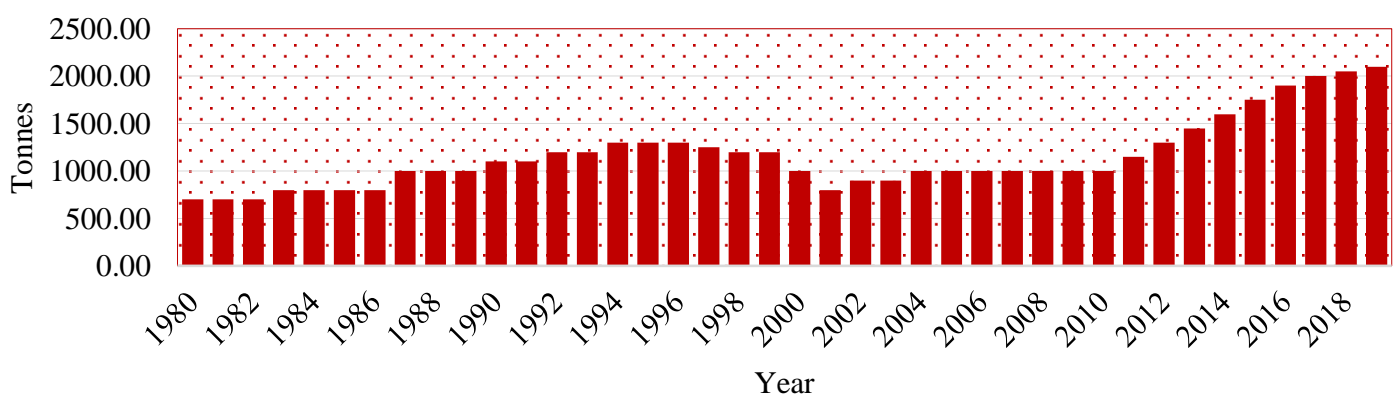

Figure 8. Afghanistan annual aquaculture production between 1980-2019 (inland).

Afghanistan aquaculture production is reported 7,950 metric tons in 2018 [37]. Among aquaculture products, fish production is multiplying. In 2019, more than 10,000 metric tons of fish produced in over 2,000 forms, mainly in Kandahar, Helmand, Urozgan, Nangarhar, Laghman, Balkh, and Nimroz province in Afghanistan [38]. In Kandahar province, over 1500 fish farms produce over 1,500 tons each month that involved over 3,500 people direct and 4,000 others indirectly that reach annual income up to 737 million AFN (9.5 million USD) [22]. The National Horticulture and Livestock Project (NHLP) in Nangarhar province build 16 fish husbandry pools by $10 \%$ beneficiaries' contribution of 58,200 AFN (750 USD) and 90\% Afghanistan Reconstruction Trust Fund (ARTF). These pools build on dry land, and each pool contains three types of 1,000 fish that result in 620,400 AFN $(8,000$ USD) net profit annually [39]. The NHLP fishery farm helps rural low-income families to start a business and generate income to improve their livelihoods. Fish farm in Oba district of Herat is one of the biggest fish productions from in Afghanistan. This farm was established five years ago, in which the first two years without production [40]. Now it is farming about 40,000 fish in five ponds. 


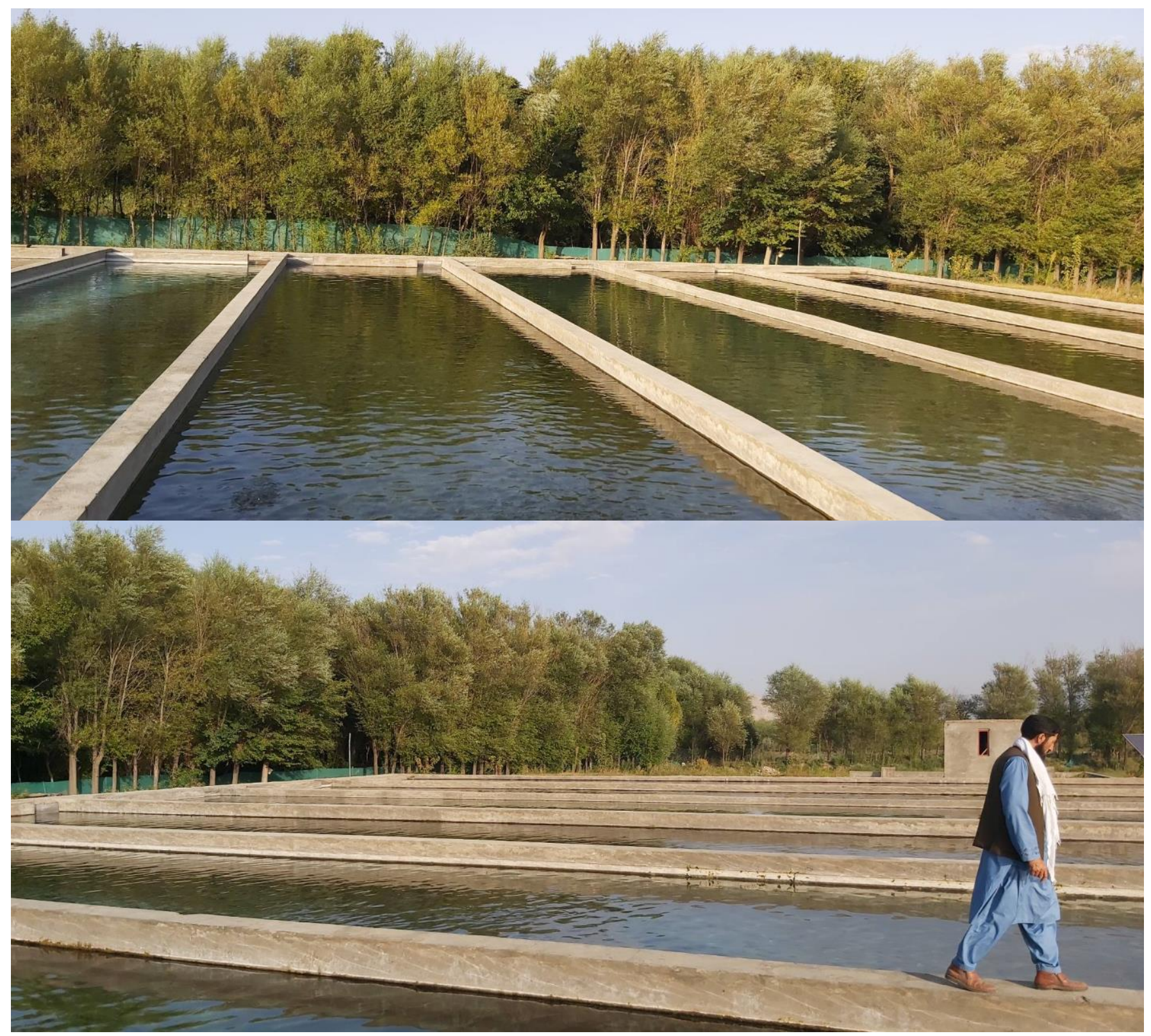

Figure 9. Fish farms in Afghanistan (A) [33,41-44]. 


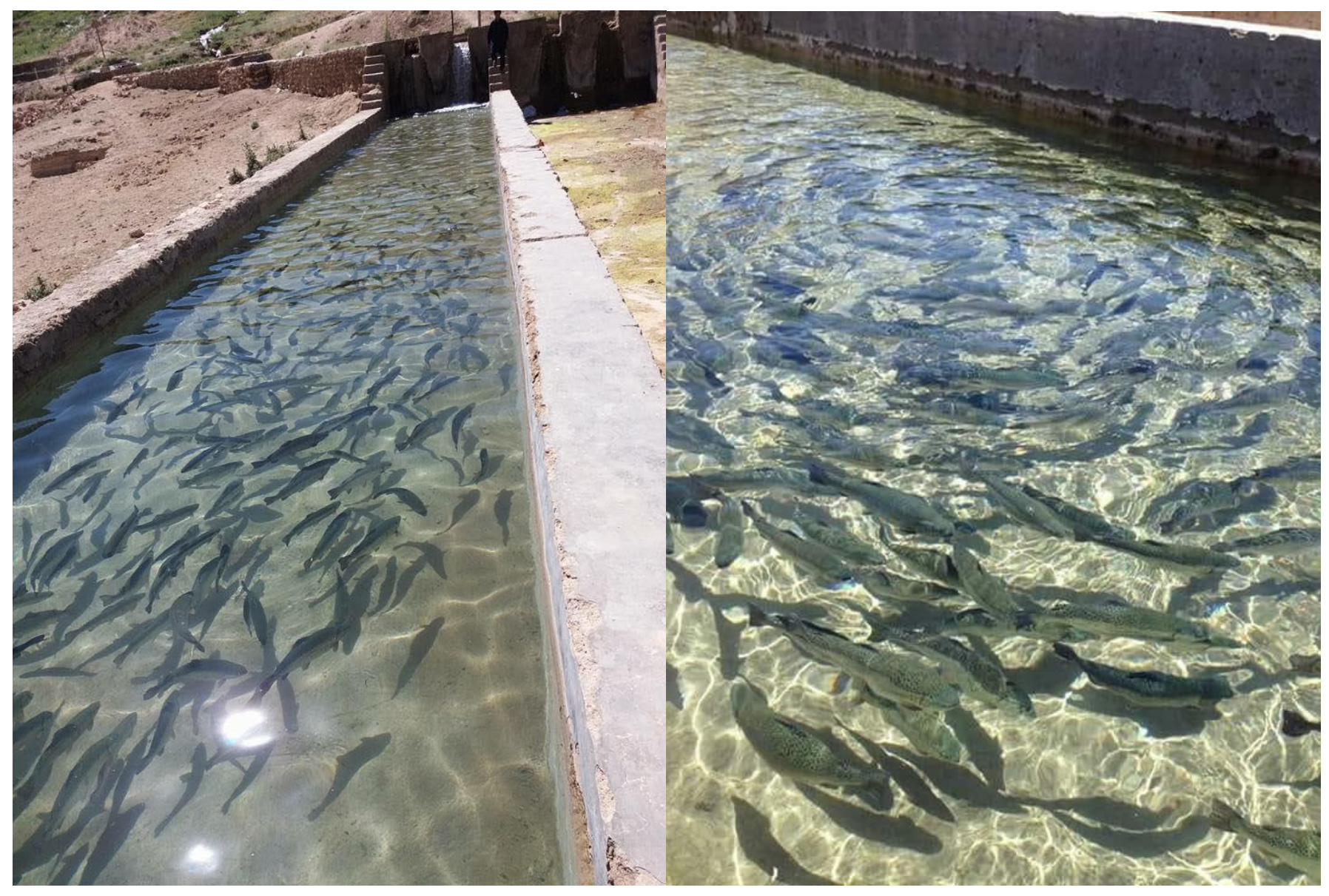

Figure 10. Fish farms in Afghanistan (B) [33,41-44].

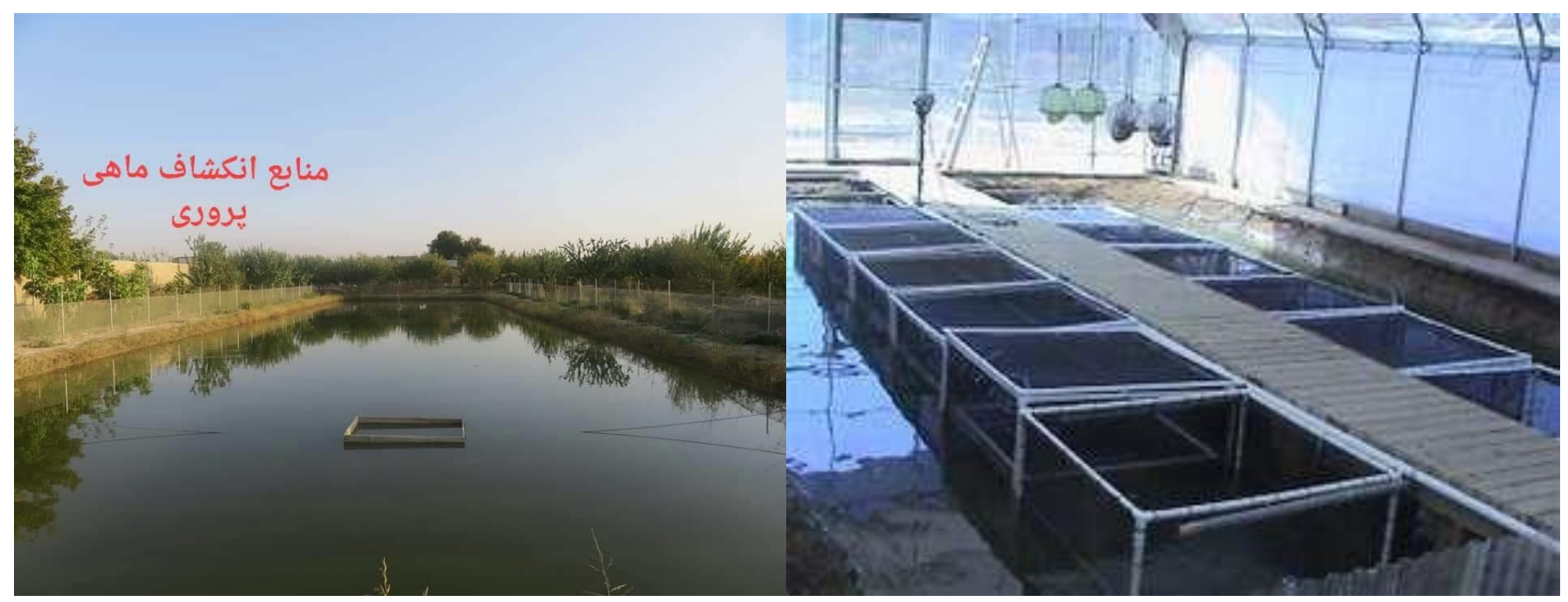

Figure 11. Fish farms in Afghanistan (C) [33,41-44]. 

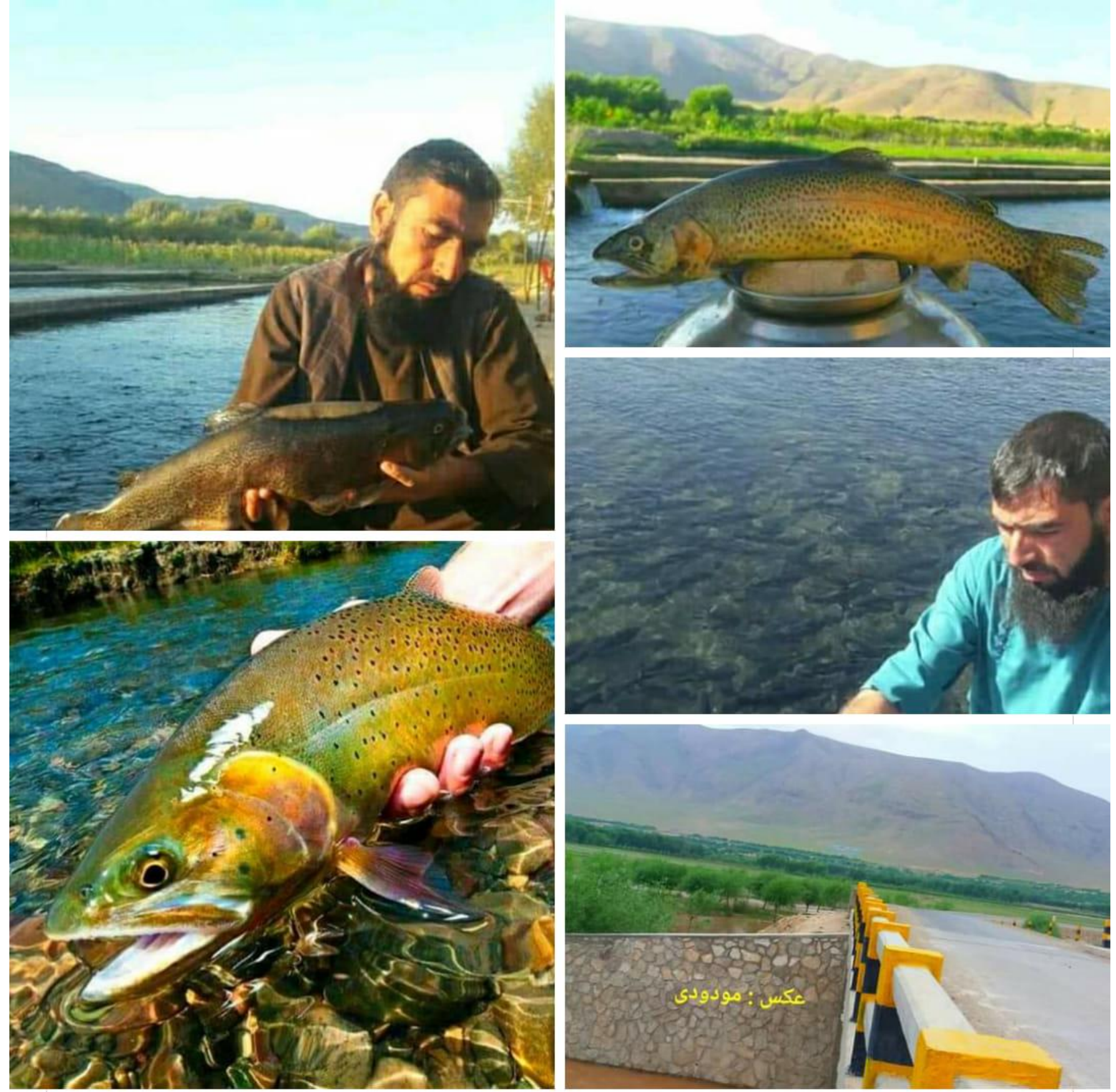

Figure 12. Oba district fish farm, Herat, Afghanistan [40].

The recent figures from Afghanistan show a significant below-average cumulative precipitation at the wet season from October 1, 2020, to February 20, 2021; likely can cause below-average agricultural and livestock production in 2021 and afterward [41]. At the same time, relatively economic activities are getting slow during the winter season, which prolongs the negative impacts of COVID19 on mostly unstable job owners' labor.

Afghanistan average production and food security status is snapshotted in Figure 13. That mostly likely highlights the situation under the stress and crisis conditions in the context of food security, which requires ample mitigation measures. 


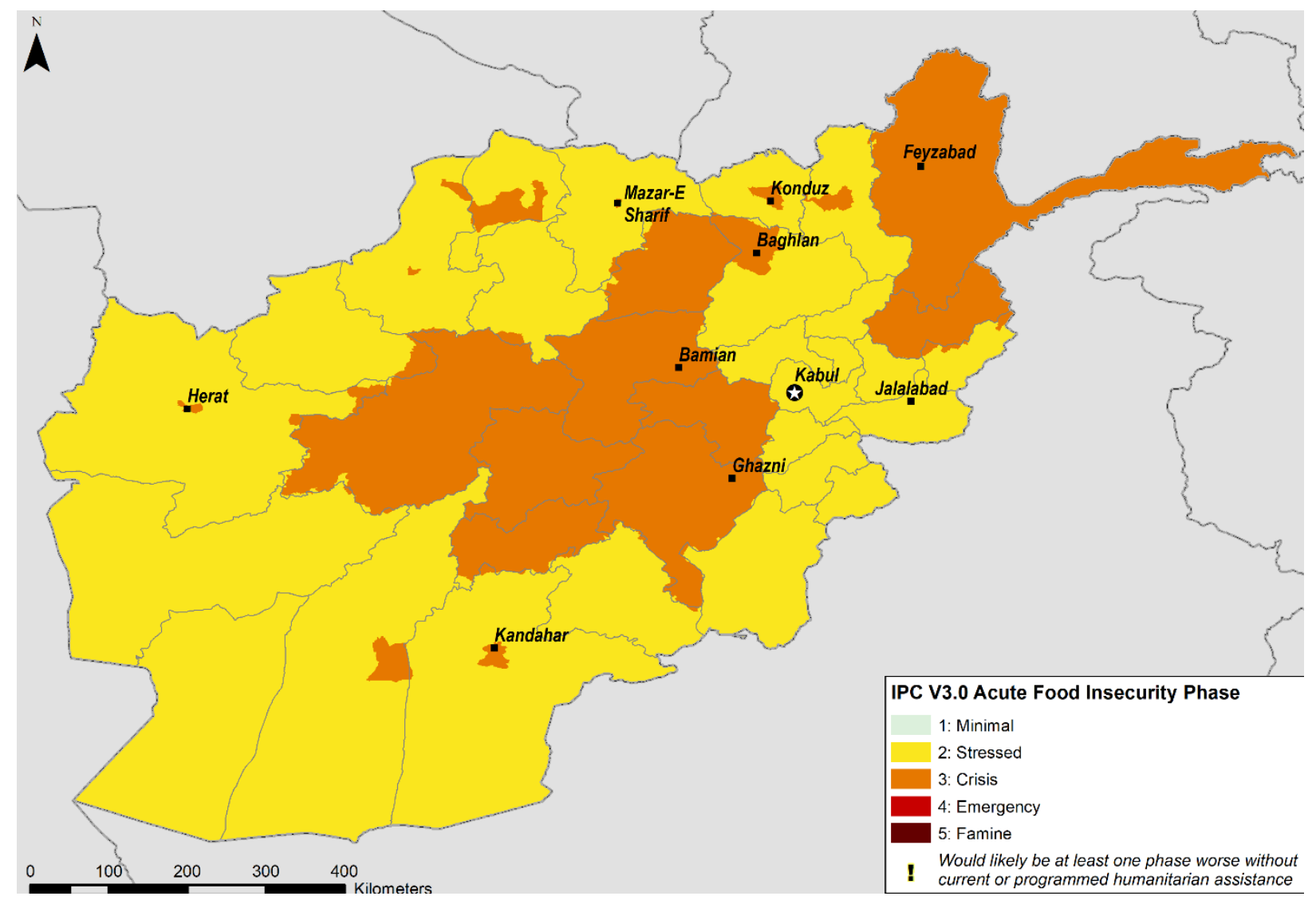

Figure 13. Afghanistan food security outlook from February - May 2021 [42].

Lamentably, recent socio-economic impacts of COVID-19, continuing conflict and insecurity incidents, the ambiguous destiny of Afghanistan 2021 peace summit in Turkey (postponed) [43], and day by day distancing people from the government offer an unexpected scenario that leads the food security situation in Afghanistan to most likely crises condition (Figure 14).

The critical situation of food insecurity induces citizens to explore local solutions that fit the increasing food demand. Therefore, aquaculture and fisheries are the most suitable measures to overcome the challenges and sustain locally sustainable food supply chains. However, in view of the recent years rapid increase in aquaculture productions (Figure 15) indicates fast-growing trends. Still, these efforts are limited to small-scale and household aquaculture and fish farms. The demand is not comparable with current production. It needs a significant transition from traditional aquaculture setups to modern aquaculture systems using cutting-edge technologies with higher farming, management, production, supply, and distribution efficiencies. 


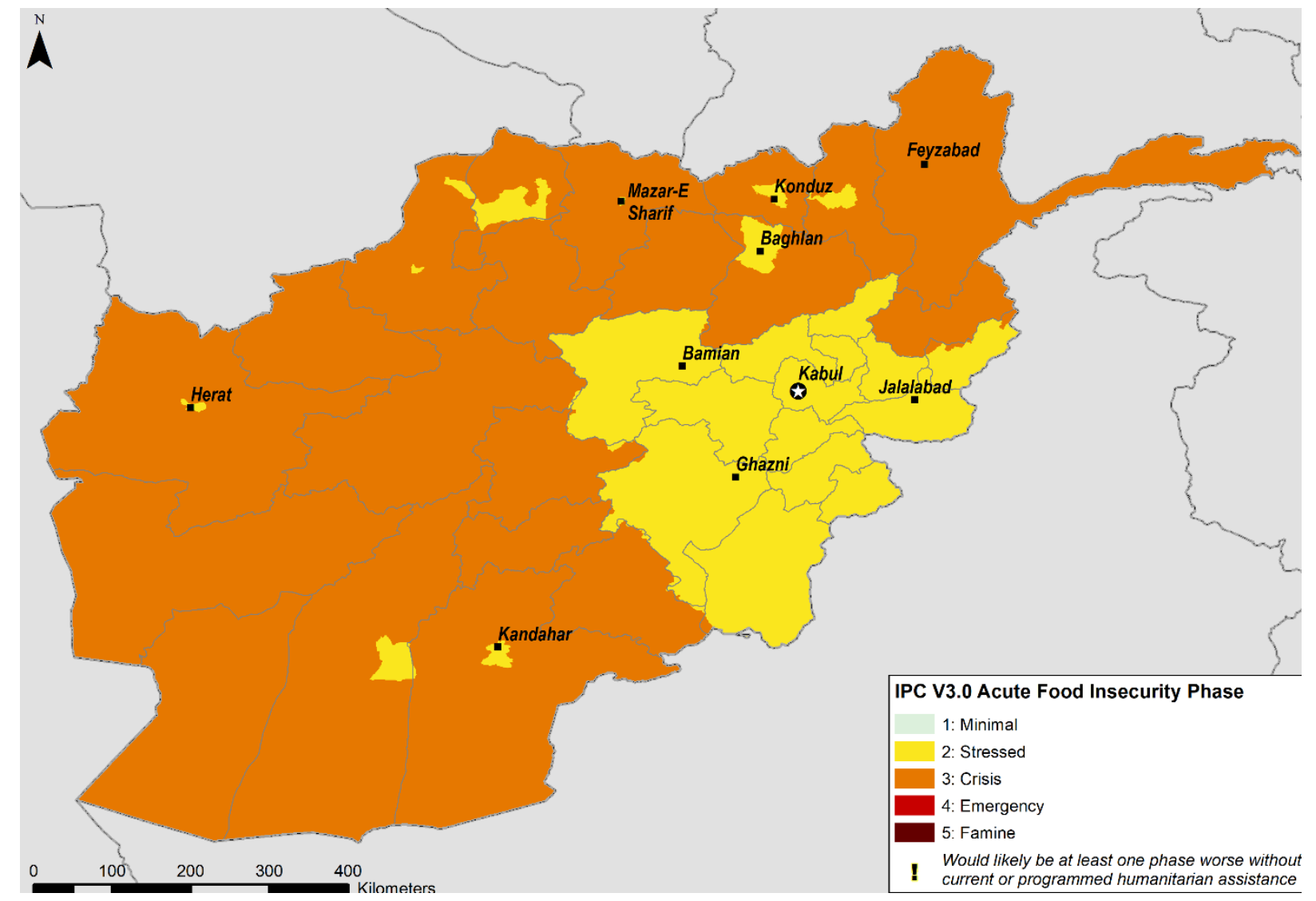

Figure 14. Afghanistan food security outlook from June - September 2021 [41]. 


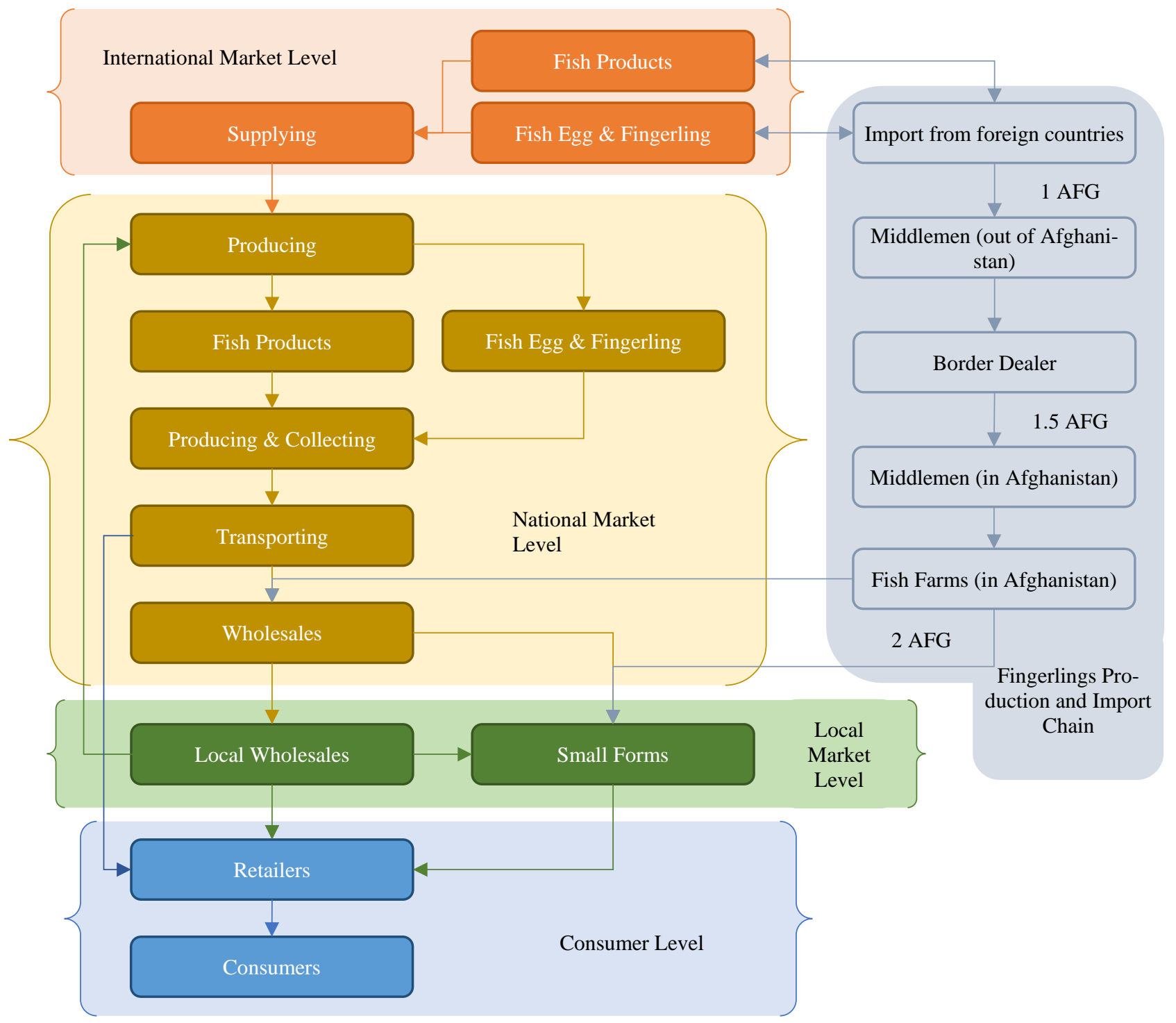

Figure 15. Afghanistan fish market supply chain (adapted from [24]).

In a general perspective, Afghanistan fishery's political, economic, social, technological, environmental, and cultural factors are detailed in [24]. Political factors are sorted in lack of interest for large-scale fish farms, frequently policy and political changes that affect the stability of market and production, insecurity, east in importing, and facilitation for foreign investment in the livestock sector. The economic factors are lack of support for initial capital and ongoing investment, economic crisis, unbalanced profit sharing at the lower, middle, and upper trade classes, limited knowledge of investors in financial accounting, lack of local facilities for transforming the system, sensitivity of market and difficulty in payback within the period. At the sociological factors, poor quality fish supply, illegal inland fishing farms, nonstandard supply chain including handling, packing and processing, and lack of food safety are highlighted. Technological factors include poor and traditional infrastructure, lack of flexibility in control and monitoring, improper hygienic safety associated with massive losses of eggs, fingerlings and so on, unavailable to harvest multiple products (agriculture and fish), lack of continued energy supply, etc. Also, environmental factors are an improper use of clean and fresh water, water pollution, inadequate sewage management, improper land use with low productivity, etc. Finally, cultural factors are deploying foreign culture within unadaptable environment, less involvement of women as the main local labor, politics influenced social and cultural behaviors and many more.

As previously reported, there is no enough information about Afghanistan aquaculture, whereby information about aquaculture and fisheries setups are not available. In a consensus, the electrical supply and distribution of aquaculture and fisheries in Afghanistan follow a simple distribution system using electrical water pumps on mostly small scales. Often single source or hybrid national grid and diesel generators (at the main or backup source) are using for aquaculture and fisheries farms in Afghanistan. Deployment of renewable energy technologies and integrating modern monitoring, operation, and control 
facilities such as the internet of things (IoT), artificial intelligence (AI), etc., are not reported. Aquaculture and fish productions in Afghanistan is not at large industrial scales.

\section{Future trends}

Density, type, culture, intensiveness, and many other factors should be considered for an appropriate and environmentally fit aquaculture production. To observe production efficiency within ecological footprint methodology and implication of horizontal integration. In which, author report in [44] estimates standing stock, annual production, and waste generation rates for the tilapia culture within estimated levels for environmental services under semi-intensive tilapia culture as: Standing stock $(0.25$ $\left.\mathrm{kg} \mathrm{m}^{-2}\right)$; annual production $\left(0.47 \mathrm{~kg} \mathrm{~m}^{-2}\right.$ year $\left.^{-1}\right)$; oxygen (consumption $1020 \mathrm{~g} \mathrm{~m}^{-2}$ year $^{-1}$, and production $2180 \mathrm{~g} \mathrm{~m}^{-2}$ year $^{-1}$ ); nitrogen output and assimilation (); phosphorus (output: $18.3 \mathrm{~g} \mathrm{~m}^{-2}$ year $^{-1}$, and assimilation $21.9 \mathrm{~g} \mathrm{~m}^{-2}$ year $^{-1}$ ). In addition to customary ecological criteria for aquatic animals and seafood recommendations, some other criteria are added newly, such as Unit of certification, stock status, non-target species, ecosystem/habitats, forage fisheries, pollution of water, loss of fishing gear, subsidies, and use of energy and CO2 emissions [45]. Environmental pollution, predominantly applies to greenhouse gases emissions such as carbon dioxide $\left(\mathrm{CO}_{2}\right)$, methane $\left(\mathrm{CH}_{4}\right)$, nitrous oxide $\left(\mathrm{N}_{2} \mathrm{O}\right)$, chlorofluorocarbons (CFCs), hydrofluorocarbons (HFCs), hydrochlorofluorocarbons (HCFCs), perfluorocarbons (PFCs), and sulfur hexafluoride (SF6) [46]. Mainly energy production and consumption contribute about $37 \%$ to global warming [8].

Advancement of aquaponics systems with high efficiency of production associated with the risk of ecosystem unbalance, using extremely natural resources of production-inputs such as farm land, water and energy supply, feeds, chemical and organic wastes that can contribute environmental distress. Also, aquaponics expansion in terms of industrial trade with high production inputs will result in similar range of production outputs that raise ecosystem and environmental concerns, comprising airborne and waterborne emissions from the farms [13]. Food and nutrition come as routine priorities after ensuring clean air (atmosphere) and soil (pollutant-free earth).

In 2015, Afghanistan produce only $1 \%$ of its fish demand inside the country, whose in the recent years fish domestic production had a significant increase but still does not meet $100 \%$ domestic demands [47]. Afghanistan government planned to establish 35,000 small to large scale fish production and 20 proliferation farms with an annual capacity of 360 tons in the next 5 years [48].

In 2020, Afghanistan had significant progress in the field of aquaculture and fishery sectors, including the establishment of 350 fish farms, preliminary surveys of water resources for building farms, practical training, preparing fish farming guidelines for 34 provinces, drafting fish farming policy including procedures, and getting approval of fishery sector development plan in Afghanistan [48].

\section{Economic and production performances indica- tors}

Optimal design and implementation of an aquaculture system depending on various factors, among all at the planning and implementation phases 1) expenditures; 2)investments; 3 ) performance variables and at the operation phase 1) production; 2) harvest and 3) marketing factors should be evaluated wisely [49]. From the literature, for small scale aquaculture, the main preliminary focus points, which are usually dealt with are water reservation and equipment proper usage as follows:

1- Reduce water circulation, replacement, evaporation, and infiltration losses.

2- Usage of proper drainage system, e.g., elbows, floodgates, and surface spillways.

Table 2: Essential variables to be applied for performance and economic indicators evaluation within a pond of a fish farm [49].

\begin{tabular}{lll}
\hline Indicators & Variables & $\begin{array}{l}\text { Pond (rec- } \\
\text { orded infor- } \\
\text { mation) }\end{array}$ \\
\hline & Cycle (months) & \\
& Water surface (ha) & \\
& Productivity (kg.ha-1) & \\
Performance & Survival rate (\%) & \\
& Apparent feed conversion & \\
& Initial body weight (kg) & \\
& Final body weight (kg) & \\
& Final stocking biomass (kg.m-2) \\
& Average variable cost (\$.kg-1) \\
& Average fixed cost (\$.kg-1) \\
& Average total cost (\$.kg-1) \\
& Gross revenue (\$.ha-1) & \\
Gross margin (\$.ha-1) & Income (\$.ha-1) \\
Economic & Gross margin index (\%) \\
& Profitability index (\%) \\
& Interest rate per month \\
\hline \hline
\end{tabular}


Table 3: Economic and production performance indicators and variables definition.

\begin{tabular}{|c|c|c|c|c|}
\hline Indicator & Abbreviation & Formula / Value & Remark & Indicator \\
\hline \multirow{9}{*}{ 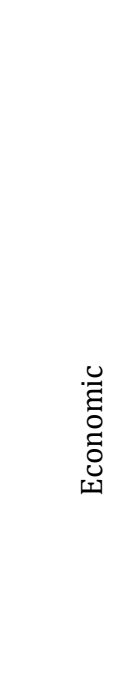 } & Gross income & GI & Gross pay & \\
\hline & Gross margin & GM & $G M=G R-V C$ & VC - Variable costs \\
\hline & Gross margin index & GMI & $G M I=\frac{G R-V C}{G R} \times 100$ & Percentage of contribution over gross income \\
\hline & Profitahility index & PI & $P V$ of $C F$ & \\
\hline & Fiomitabinty index & 11 & $P I=\overline{\text { Initial investment }}$ & \\
\hline & Present value & PV & $P V=\frac{C F}{(1+r)^{t}}$ & $\begin{array}{l}r \text { - Discount rate } \\
t \text { - Number of years }\end{array}$ \\
\hline & Profit & $\mathrm{P}$ & $P=G R-T C$ & \\
\hline & Gross revenue & GR & $\mathrm{GR}=q \times p$ & $\begin{array}{l}\text { Revenue that resulted from sales } \\
\text { q - Quantity sold } \\
\text { p - Selling price }\end{array}$ \\
\hline & Total cost & $\mathrm{TC}$ & $V C-F C$ & FC - Fixed costs \\
\hline \multirow{7}{*}{ 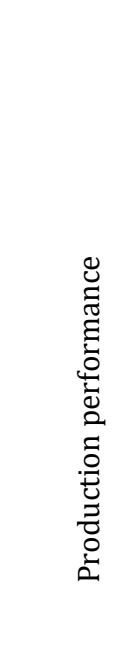 } & Average variable cost & AVC & $\frac{\text { Monetary unit (USD) }}{k a}$ & Ratio between cost and quantity produced \\
\hline & Equilibrium point & EP & $\frac{\mathrm{FC}}{p-A V C}\left((\text { ha. } \mathrm{yr})^{-1}\right)$ & $\begin{array}{l}\text { Minimum production level needed to offset } \\
\text { total costs, at a given selling price (p) }\end{array}$ \\
\hline & Production cycle & $\mathrm{PC}$ & length of production cycle & Month \\
\hline & $\begin{array}{l}\text { Apparent feed conver- } \\
\text { sion }\end{array}$ & $\mathrm{FC}$ & $\frac{\text { Feed consumed }(\mathrm{kg})}{\text { Weight gained }(\mathrm{kg})}$ & At a PC \\
\hline & Average biomass storage & $\mathrm{ABS}$ & $\frac{\text { Live weight }}{m^{2}}$ & \\
\hline & Survival index & SI & 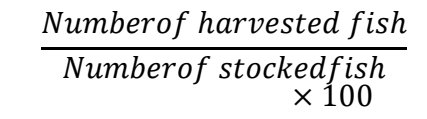 & Percentage $(\%)$ \\
\hline & Final average weight & FAW & $\frac{\text { Total harvested weight }}{\text { Numberof harvested fish }}$ & $\mathrm{kg}$ \\
\hline
\end{tabular}

\section{Result and discussion}

There is a tribble history of human animosity with nature and themselves, aggressions, wars, conflicts, and most tragically, global warming and climate changes. That leads nations to shape the world imprudently with deficient and egocentric policies. For example, capitalism can cause global inequality, market failure, climate and ecosystem changes distress, short-termism, excess materialism, and boom and bust economic cycles [50]. While the capitalist system needs serious attention that had adverse impact on climate change, environmentalists strictly advise mitigating climate change in the long term by transforming the capitalist system [51]. Since pre-industrial time, climate changes (air temperature rising) contribution due to greenhouse gases (GHGs) emotions recorded 56\% and $44 \%$ by developed and developing countries, respectively [52].
The basic criteria for successful aquaculture deployment in the context of household and small systems in developing countries are adding up in Figure 16.

Land, water, and energy resources are the main pursual elements of an aquaculture system. Afghanistan's aquaculture and fisheries setups are not well-developed to meet the recent technologies for smart and automatic operation and supply, i.e., internet of things (IoT), artificial intelligence (AI), etc. In the case of Afghanistan, smallscale aquaculture and fish farms establish next to rivers using water diversion techniques, adjacent to rivers using water pumps, land with water sources drawing from groundwater, ponds within irrigation systems (seasonal), pons fed by springs water [21].

All told, for the successful operation of small aquaculture systems, the criteria mentioned above should be satisfied, and elements should be ordered according to their optimum efficiency. Often, the system will not meet the optimum outcome in the absent or incorrect deployment of the features. It needs re-engineering to develop optimal 
operation and outcome, which mainly deal with water temperature control, water circulating optimization, intensification of production, overall risk mitigation, etc.

Fish feeding represents up to $50 \%$ of operation cost at small-scale fish farms that require a good feeding strategy to maintain variety of feeding. That includes factory, home, the mixture of agricultural waste, and fertilizing ponds with manures/fertilizers in the form of pellet/paste/ground feed [21].

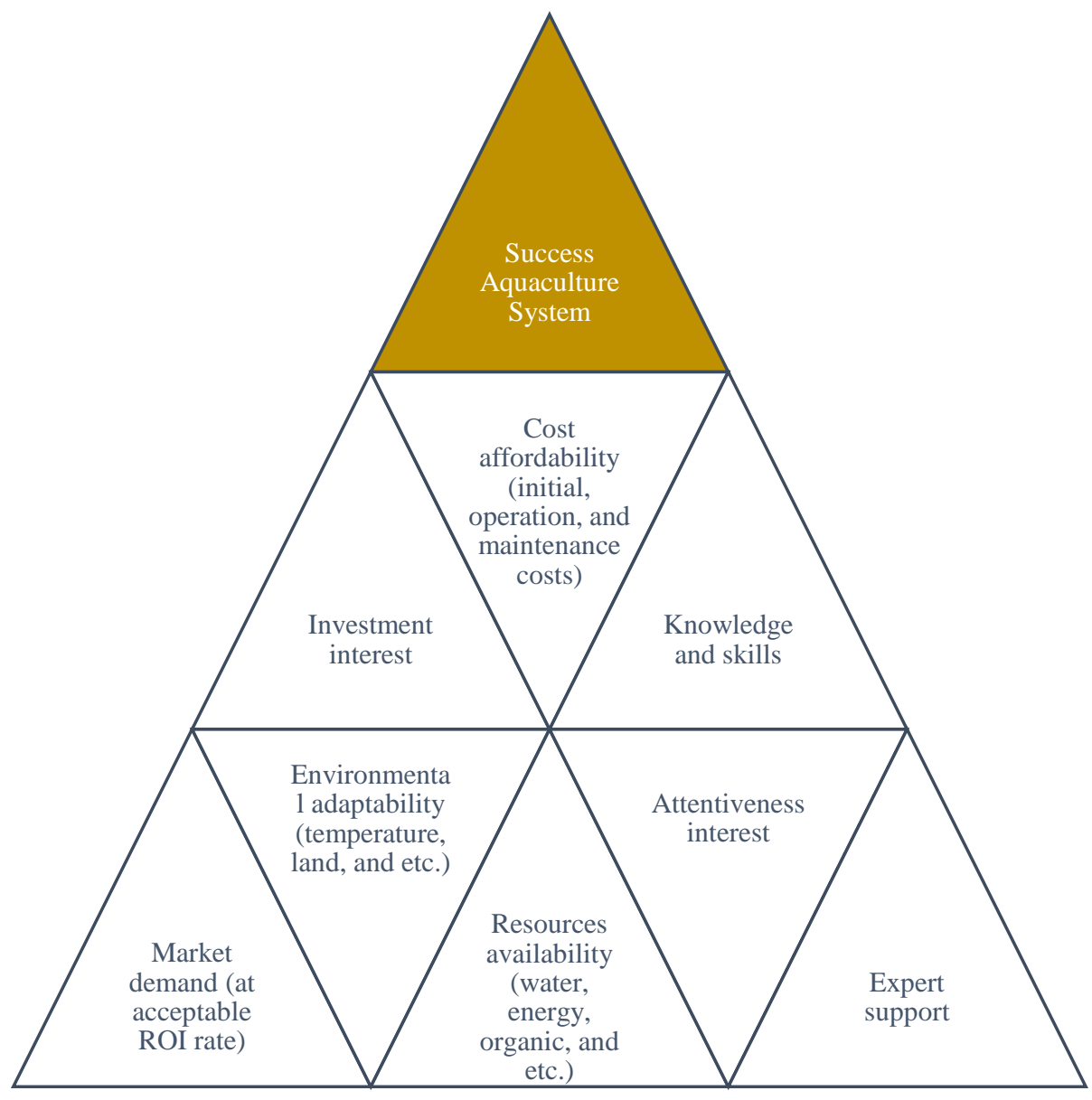

Figure 16. Basic criteria for successful small-scale aquaculture.

\section{Recommendation}

Ensuring peace, dignity, and equality on a healthy planet declaration of United Nations (UN) [53], Article 25 of The Universal Declaration of Human Rights [54] "Everyone has the right to a standard of living adequate for the health and well-being of himself and of his family, including food, clothing, housing and medical care and necessary social services, and the right to security in the event of unemployment, sickness, disability, widowhood, old age or other lack of livelihood in the circumstances beyond his control." caring societies are a united and individual efforts to conduct responsibly and sustainably. Following this guideline, exploring cost-effective solutions for national empowerment and self-sufficiency come to the priority. Among many solutions, aquaponics, aquaculture, and fisheries production in terms of large industrial scale can mitigate the current food security issue in Afghanistan by creating wealth and jobs for thousands of the citizens, which needs exhaustive feasibility studies and research efforts, to sum up with a viable long-term solution. However, there are many factors to discuss and many questions to respond to. Still, this study highlights the main factors that significantly impact the successful implementation of aquaponics or an aquaculture system within sustainability requirements.

At the topic of aquaponics and aquaculture, including crops, livestock, fisheries, and forestry, it recommended to improve efficiency and equity of economic systems and facilitate transformation by linking rural and urban economy to ensure economic-wide income-earning opportunities, effective social protection, and competitive and equitable domestic and international markets for inputs and outputs [55].

As fishery sectors remain demanding local business, observation and proper solution for efficient fishery sectors are required (Figure 17). 


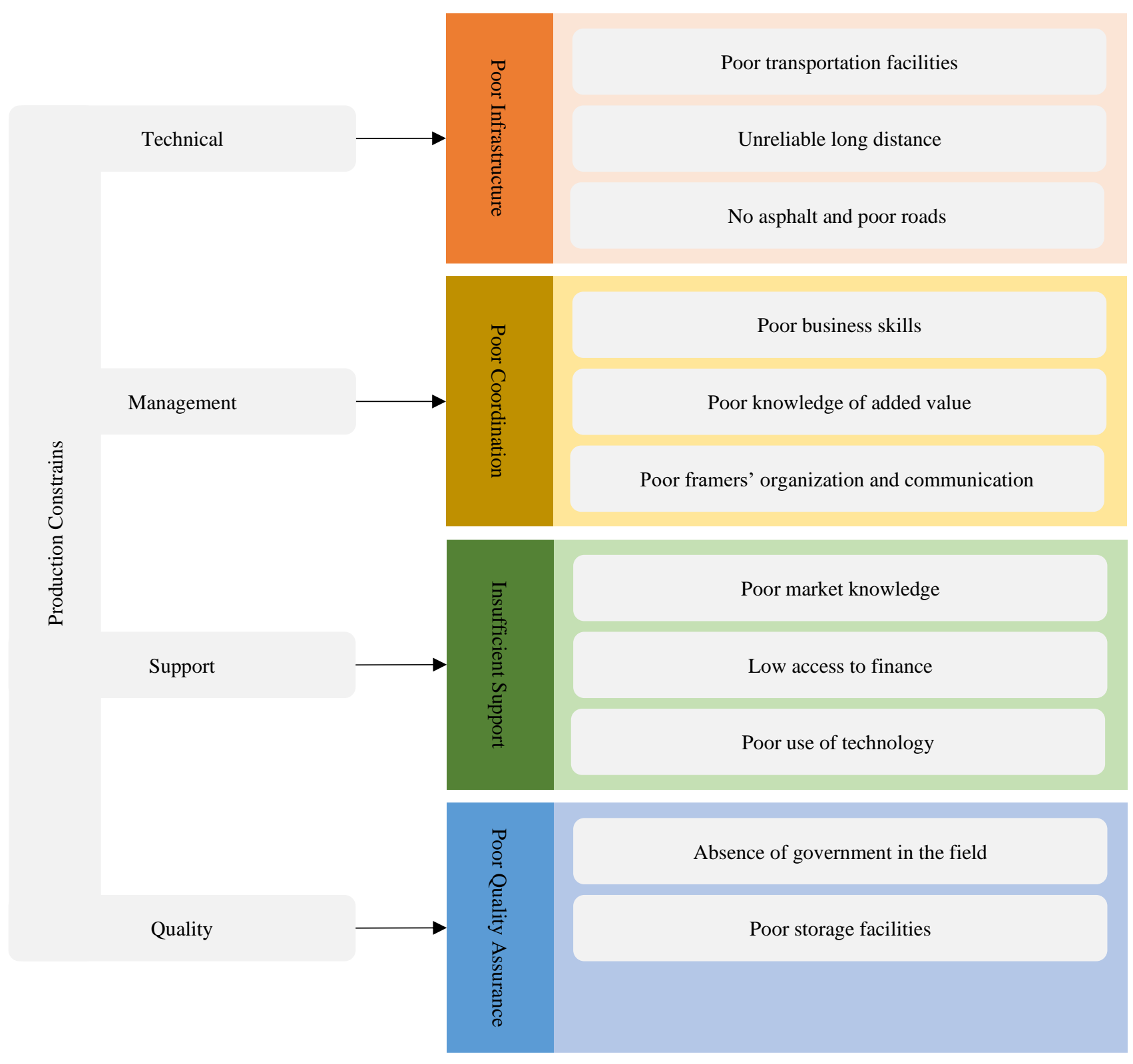

Figure 17. Constraints on the way of fishery sector in Afghanistan (adapted from [24]).

In an early outlook, aquaponics industrial activities incorporated environmental and natural resources distress within the ecosystem that knew potential risks for environmental sustainability although human health [13]. Therefore, aquaponics systems life cycle assessment (LCA), proficient policy formulation, and viable management and operation decision-making within environmental sustainability are known exigence.

Advanced setup and technology employment over traditional aquaculture associated with some advantages such as reducing land use, saving water and energy consumption, increase plant and fish production, establish a controlled environment, increase efficiency, optimize equipment use, make easy the operation and monitoring, eliminate effluents, create multiple harvesting simultaneously, and many more. Therefore, within a few efforts and reforms, the conventional aquaculture and fisheries productions in Afghanistan can be transformed into advanced systems consisting of many advantages, importantly, saving resources (land, water, energy, labor, etc.) and reducing biodiversity and ecosystem distress at a controlled environment.

\section{Conclusion}

Food security crises and COVID-19 socio-economic impacts lead developing nations to dramatic tragedy. That implies nations seeking alternatives for maintaining healthy food and nutrition. Simultaneously, day by day increasing demand due to population growth in the world, scholars and researchers draw cost-effective solutions for long-run sustainability. As aforementioned, aquaculture is one of the short to long-term solutions for developing nations to ensure local aquatic foods and plants and create wealth and jobs for thousands of citizens. 
Following the global success history of aquaculture and fishery systems, improvement and resiliency of these systems in Afghanistan are recommended. This is essential to transform conventional setups into modern systems with high tenacity of coping functionality and efficiency within suitability requirements. Also, utilizing modern aquaculture and fishery farms mitigates environmental distress and prevents biodiversity and ecosystem impacts.

Until recently, there is no specific publication on the subject that forced on Afghanistan aquaculture and fishery in the form of a scholarly journal. Therefore, this study will be a good reference for students, researchers, scholars, and practitioners interested in Afghanistan aquaculture and fishery studies.

\section{Acknowledgment}

This case review study is conducted as part of an ongoing pilot project (Nakagusuku Aquaculture Innovation Center (NAICe)). This project, proposed in four segments, marine science studies, aquaculture systems development, sustainable energy deployment, and socio-economic business modeling, aims to improve society resiliency and contribute to sustainable development goals (SDGs) five goals (2, $7,8,12$, and 14). This work is part of a research study that University of the Ryukyus financially and technically supports.

\section{References}

[1] QU Dongyu (2016) "FAO corporate video" (https://www.youtube.com/watch?v=Ub6N8aWThw4\&t=58s) Accessed: 27 April 2021

[2] Danish MSS, Matayoshi H, Howlader HOR, Chakraborty S, Mandal P, et al. (2019) "Microgrid Planning and Design: Resilience to Sustainability" 2019 IEEE PES GTD Grand International Conference and Exposition Asia (GTD Asia) Bangkok, Thailand, IEEE - pp. 253-258. https://doi.org/10.1109/GTDAsia.2019.8716010 (https://ieeexplore.ieee.org/document/8716010/) Accessed: 28 September 2019

[3] Danish MSS, Sabory NR, Ershad AM, Danish SMS, Ohta R, et al. (2017) "The Least Developed Countries Need for Changing the Passive Trend of Renewable Energy Exploitation to a Proactive Trend" International Journal of Energy and Power Engineering (vol. 5, no. 6, pp. 215-221) https://doi.org/10.11648/j.ijepe.20160506.17

[4] O'Neill-Carrillo E, Irizarry-Rivera AA, Colucci-Rios JA, Perez-Lugo M, Ortiz-Garcia C (2008) "Sustainable Energy: Balancing the Economic, Environmental and Social Dimensions of Energy" 2008 IEEE Energy 2030 Conference Atlanta, GA, USA, IEEE - pp.1-7. https://doi.org/10.1109/ENERGY.2008.4781010 (http://ieeexplore.ieee.org/document/4781010/) Accessed: 21 July 2019

[5] Brundtland G (1987) "Report of the World Commission on Environment and Development: Our Common Future" New York, USA, United Nations (UN). (https://sustainabledevelopment.un.org/content/documents/5987our-common-future.pdf)
[6] Danish MSS, Senjyu T, Ibrahimi AM, Ahmadi M, Howlader AM (2019) "A managed framework for energy-efficient building" Journal of Building Engineering (vol. 21, pp. 120128) https://doi.org/10.1016/j.jobe.2018.10.013

[7] Danish MSS, Senjyu T, Sabory NR, Danish SMS, Ludin GA, et al. (2017) "Afghanistan's aspirations for energy independence: Water resources and hydropower energy" Renewable Energy (vol. 113, pp. 1276-1287) https://doi.org/10.1016/j.renene.2017.06.090

[8] Danish MSS, Sabory NR, Ershad AM, Danish SMS, Yona A, et al. (2016) "Sustainable Architecture and Urban Planning trough Exploitation of Renewable Energy" International Journal of Sustainable and Green Energy (vol. 6, no. 3, pp. 1) https://doi.org/10.11648/j.ijrse.s.2017060301.11

[9] Coad B: editor (2014) "Fishes of Afghanistan," 1st ed. Enabled, Pensoft. 389 p. ISBN: 954-642-752-7

[10] Pandey VL, Mahendra Dev S, Jayachandran U (2016) "Impact of agricultural interventions on the nutritional status in South Asia: A review" Food Policy (vol. 62, pp. 28-40) https://doi.org/10.1016/j.foodpol.2016.05.002

[11] Stobutzki IC, Silvestre GT, Garces LR (2006) "Key issues in coastal fisheries in South and Southeast Asia, outcomes of a regional initiative" Fisheries Research (vol. 78, no. 2-3, pp. 109-118) https://doi.org/10.1016/j.fishres.2006.02.002

[12] Nash CE (2011) "The history of aquaculture," 1st ed. Ames, Iowa, Wiley-Blackwell. 227 p. ISBN: 978-0-8138-2163-4

[13] Samuel-Fitwi B, Wuertz S, Schroeder JP, Schulz C (2012) "Sustainability assessment tools to support aquaculture development" Journal of Cleaner Production (vol. 32, pp. 183192) https://doi.org/10.1016/j.jclepro.2012.03.037

[14] FAO (2020) "The state of world fisheries and aquaculture 2020: Sustainability in action," 1st ed. Rome, Italy, Food and Agriculture Organization of the United Nations (FAO). 244 p. ISBN: 978-92-5-132692-3 (http://www.fao.org/documents/card/en/c/ca9229en/) Accessed: 22 April 2021

[15] Levis JW, Weisbrod A, Van Hoof G, Barlaz MA (2017) “A review of the airborne and waterborne emissions from uncontrolled solid waste disposal sites" Critical Reviews in Environmental Science and Technology (vol. 47, no. 12, pp. 1003-1041) https://doi.org/10.1080/10643389.2017.1342513

[16] United Nations (UN) (2020) "The17 Goals: Sustainable development" Department of Economic and Social Affairs - UN (https://sdgs.un.org/goals) Accessed: 22 April 2021

[17] Sustainable aquaculture (2021) Better Fish Farming (https://www.betterfishfarming.org/) Accessed: 22 April 2021

[18] Cai J, Zhou X, Yan X, Lucente D, Lagana C (2019) “Top 10 species groups in global aquaculture 2017" Food and Agriculture Organization of the United Nations (FAO) (pp. 12)

[19] Idayzone (2017) "Qargha lake" IDAYZONE (https://idayzone.wordpress.com/2017/10/03/qarghalake/) Accessed: 30 April 2021

[20] FAO (2017) "Taming the waters of Afghanistan" Detail video, Food and Agriculture Organization of the United $\mathrm{Na}$ tions (http://www.fao.org/news/audio-video/detailvideo/en/c/12197/?uid=12197) Accessed: 27 April 2021 
[21] Funge-Smith S, Yousafzai KR, Durani HLM, Salimi HLM, Rahman S, et al. (2008) "The Potential for Aquaculture Development in Afghanistan" Asia Pacific Fishery Commission AD HOC Publicaiton (pp. 1-38)

[22] Xinhuanet (2019) "Fish farming booms in S. Afghan province" Asia and Pasific (http://www.xinhuanet.com/english/2019-07/14/c_138225783.htm) Accessed: 25 April 2021

[23] Afghan Trout Fish Farm (2018) "New arrived fish to Kabul" (https://www.facebook.com/426690291080164/photos/a.426728447743015/433807987035061/) Accessed: 27 April 2021

[24] Ahmadzai B (2017) "Fish value chain analysis and fisheries sector development opportunities: Afghanistan" Technical Report Kabul, Afghanistan, Ministry of Agriculture Irrigation and Livestock (MAIL), Afghanistan. (https://www.researchgate.net/publica-

tion/316985997_Fish_Value_Chain_Analysis_and_Fisheries_Sector_Development_Opportunities-Afghanistan) Accessed: 21 April 2021

[25] List of freshwater fish of Afghanistan (2021) Mongabay (http://www.mongabay.com/data/Afghanistan.htm) Accessed: 28 April 2021

[26] List of freshwater fishes reported from Afghanistan (2021) FishBase (https://www.fishbase.de/country/CountryCheck-

list.php?showAll=yes $\&$ what $=$ list $\& \operatorname{trpp}=50 \& c_{-}$code $=004 \& c$ presence $=$ Reported $\&$ sortby $=$ al -

pha2\&ext_CL=on\&ext_pic=on\&vhabitat=fresh) Accessed: 26 April 2021

[27] Pariona A (2019) "Native fish of Afghanistan" WorldAtlas (https://www.worldatlas.com/articles/native-fish-of-afghanistan.html) Accessed: 24 April 2021

[28] FAO: editor (2018) "The state of world fisheries and aquaculture 2018 - Meeting the sustainable development goals," 1st ed. Rome, Italy, Food and Agriculture Organization of the United Nations (FAO). 210 p. ISBN: 978-92-5-130562-1

[29] Shahed (2020) "Fish farming in Afghanistan, six months waiting for harvesting" Shahed News (https://shahed.news/2020/09/-برورش-ماهى-در -افغانســتان، (9) Accessed: 29 April 2021

[30] Partoopars Fish Farm (2021) "Afghan fish kabab (1)" (https://www.facebook.com/farmahi.partoopars/photos/pcb.893299511426341/893299354759690) Accessed: 30 April 2021

[31] Partoopars Fish Farm (2021) "Afghan fish kabab (2)" (https://www.facebook.com/farmahi.partoopars/photos/pcb.893299511426341/893299391426353) Accessed: 30 April 2021

[32] Partoopars Fish Farm (2021) "Salmon species fish in Afghanistan" (https://www.facebook.com/farmahi.partoopars/pho-

tos/pcb.765796457509981/765796047510022) Accessed: 30 April 2021

[33] Partoopars Fish Farm (2021) "Salmon fish kabak" (https://www.facebook.com/farmahi.partoopars/photos/pcb.765796457509981/765796330843327) Accessed: 30 April 2021

[34] Partoopars Fish Farm (2021) "Salmon fish ready for kabak" (https://www.facebook.com/farmahi.partoopars/photos/pcb.765796457509981/765795984176695) Accessed: 30 April 2021

[35] FAO (2021) "Fishery and aquaculture country profiles: The Islamic Republic of Afghanistan" Fisheries Division - FAO (http://www.fao.org/fishery/facp/AFG/en) Accessed: 27 April 2021

[36] UNHCR (2009) "Fish farming and food-for-work Afghanistan" Story Geneva, Switzerland, United Nations High Commissioner for Refugees (UNHCR). (https://www.unhcr.org/uk/4ad72cf39.pdf) Accessed: 24 April 2021

[37] Trading Economics (2021) "Afghanistan: Aquaculture Production (metric Tons) 1969-2018 Data" (https://tradingeconomics.com/afghanistan/aquacultureproduction-metric-tons-wb-data.html) Accessed: 27 April 2021

[38] Ministry of Agriculture, Irrigation and Livestock, Afghanistan (2019) "Afghanistan produces 10,000 tons fish annually" (https://www.youtube.com/watch?v=0sChOjEVd0I) Accessed: 27 April 2021

[39] Livestock and fish farming bring self-sufficiency to rural Afghans (2018) World Bank (https://www.worldbank.org/en/news/feature/2018/10/28/livestock-and-fish-farming-spur-ruralafghans-toward-self-sufficiency) Accessed: 28 April 2021

[40] Livestock informations (2021) (https://www.facebook.com/20531316728/posts/10154009990506729/) Accessed: 8 May 2021

[41] Food security outlook: Below-average precipitation likely to drive below-average agricultural and livestock production in 2021 (2021) Situation Report USA, Famine Early Warning Systems Network (FEWS NET). (https://reliefweb.int/report/afghanistan/afghanistan-food-security-outlook-february-september-2021) Accessed: 29 April 2021

[42] Famine Early Warning Systems Network (FEWS NET) (2021) "Afghanistan: Overall average production and income expected from second season crops" Afghanistan Food security outlook: October 2020 - May 2021 (https://fews.net/central-asia/afghanistan/food-securityoutlook/october-2020) Accessed: 29 April 2021

[43] Turkey postpones Afghanistan peace summit over Taliban no-show (2021) Aljazeera (https://www.aljazeera.com/news/2021/4/21/turkeypostpones-afghanistan-peace-summit-over-taliban-noshow) Accessed: 29 April 2021

[44] Bunting SW (2001) "Appropriation of environmental goods and services by aquaculture: A reassessment employing the ecological footprint methodology and implications for horizontal integration" Aquaculture Research (vol. 32, no. 7, pp. 605-609) https://doi.org/10.1046/j.13652109.2001.00563.x

[45] James Sullivan Consulting (2012) "Smart fishing initiative: Comparison of wild-capture fisheries certification schemes" Gland, Switzerland, WWF - World Wide Fund For Nature.

[46] Danish MSS, Zaheb H, Sabory NR, Karimy H, Faiq AB, et al. (2019) "The Road Ahead for Municipal Solid Waste Management in the 21st Century: A Novel-standardized Simulated Paradigm" IOP Conference Series: Earth and 
Environmental Science IOP Publishing, vol. 291 - pp. 1-5. https://doi.org/10.1088/1755-1315/291/1/012009

[47] Sayed Azim Arash (2015) "Establishing hundreds of fish farms in Afghanistan due to increase in demand" BBC News Farsi (https://www.bbc.com/persian/afghanistan/2015/09/150902_k04_fish_farm_in_afghanistan) Accessed: 30 April 2021

[48] Forough K (2020) "Fish farming in Afghanistan" Ministry of Agriculture, Irrigation and Livestock (MAIL), Afghanistan (https://www.mail.gov.af/dr/node/4228) Accessed: 30 April 2021

[49] Barros AF de, Martins MIEG (2012) "Performance and economic indicators of a large scale fish farming in Mato Grosso, Brazil" R Bras Zootec (vol. 41, no. 6, pp. 1325-1331) https://doi.org/10.1590/S1516-35982012000600001

[50] Pettinger T (2019) "Problems of capitalism" Economics Help (https://www.economicshelp.org/blog/77/economics/problems-of-capitalism/) Accessed: 22 April 2021

[51] Fletcher R (2012) "Capitalizing on chaos: Climate change and disaster capitalism" Ephemera theory \& politics in org anization (vol. 12 , no. $1 / 2$, pp. 97-112)

[52] Wei T, Dong W, Yan Q, Chou J, Yang Z, et al. (2016) "Developed and developing world contributions to climate system change based on carbon dioxide, methane and nitrous oxide emissions" Advances in Atmospheric Sciences (vol. 33, no. 5, pp. 632-643) https://doi.org/10.1007/s00376-0155141-4

[53] United Nations (UN) (1948) "Universal Declaration of Human Rights" United Nations (https://www.un.org/en/about-us/universal-declarationof-human-rights) Accessed: 29 April 2021

[54] United Nations (UN) (2021) "Article 25 of the universal declaration of human rights" United for Human Rights (https://www.humanrights.com/course/lesson/articles19-25/read-article-25.html) Accessed: 29 April 2021

[55] FAO (2018) "The future of food and agriculture - Alternative pathways to 2050," 1st ed. Rome, Italy, Food and Agriculture Organization of the United Nations (FAO). 60 p. ISBN:

978-92-5-130989-6 (http://www.fao.org/3/CA1553EN/ca1553en.pdf) 